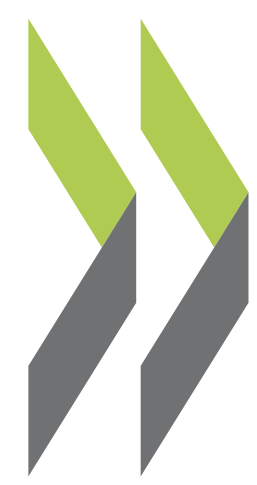

OECD Economics Department Working Papers No. 1677

The COVID-19 shock and productivity-enhancing reallocation in Australia: Real-time evidence from Single Touch Payroll

\section{Dan Andrews,}

\author{
Jonathan Hambur,
} Elif Bahar 
ECONOMICS DEPARTMENT

THE COVID-19 SHOCK AND PRODUCTIVITY-ENHANCING REALLOCATION IN AUSTRALIA: REAL-TIME EVIDENCE FROM SINGLE TOUCH PAYROLL

\section{ECONOMICS DEPARTMENT WORKING PAPERS No. 1677}

By Dan Andrews, Elif Bahar and Jonathan Hambur

OECD Working Papers should not be reported as representing the official views of the OECD or of its member countries. The opinions expressed and arguments employed are those of the author(s).

Authorised for publication by Luiz de Mello, Director, Policy Studies Branch, Economics Department.

All Economics Department Working Papers are available at www.oecd.org/eco/workingpapers 
OECD Working Papers should not be reported as representing the official views of the OECD or of its member countries. The opinions expressed and arguments employed are those of the author(s).

Working Papers describe preliminary results or research in progress by the author(s) and are published to stimulate discussion on a broad range of issues on which the OECD works.

Comments on Working Papers are welcomed, and may be sent to OECD Economics Department, 2 rue André Pascal, 75775 Paris Cedex 16, France, or by e-mail to eco.contact@oecd.org.

All Economics Department Working Papers are available at www.oecd.org/eco/workingpapers

(C) OECD (2021)

You can copy, download or print OECD content for your own use, and you can include excerpts from OECD publications, databases and multimedia products in your own documents, presentations, blogs, websites and teaching materials, provided that suitable acknowledgment of OECD as source and copyright owner is given. All requests for commercial use and translation rights should be submitted to Pubrights@oecd.org 


\section{ABSTRACT/RESUME}

\section{COVID-19 and Productivity-Enhancing Reallocation in Australia: Real-time evidence from Single Touch Payroll}

The consequences of the pandemic for potential output will partly hinge on its impact on high productivity firms, and more generally the ongoing process of productivity-enhancing reallocation - the rate at which scarce resources are reallocated from less productive to more productive firms. While Schumpeter (1939) originally proposed that recessions can accelerate this process, the more 'random' nature of the COVID19 shock coupled with a policy response that prioritised preservation (over reallocation) raises questions about whether job reallocation remained productivity-enhancing over the course of the pandemic. Despite these headwinds, our analysis based on novel high-frequency employment data for Australia shows that job reallocation (and firm exit) remained solidly connected to firm productivity over 2020. The greater resilience of high productivity firms is significant, given that an indiscriminate shakeout of such firms - and the associated destruction of firm-specific intangible capital - would have imparted significant scarring effects. As it turns out, the temporary nature of Australia's job retention scheme (JobKeeper) made an important (and surprising) positive contribution to this process, with material consequences for aggregate productivity. But the scheme appears to have become more distortive over time, justifying its timely withdraw - on productivity grounds at least.

JEL classification codes: E24, E32, J63, O4.

Keywords: COVID-19, productivity, reallocation, recessions.

\section{COVID-19 et réaffectation améliorant la productivité en Australie : preuves en temps réel de la paie à simple contact}

Les conséquences de la pandémie sur la production potentielle dépendront en partie de son impact sur les entreprises à forte productivité, et plus généralement de son impact sur le processus de réallocation le rythme auquel les ressources sont réaffectées des entreprises moins productives vers les entreprises plus productives. Alors que Schumpeter (1939) a proposé que les récessions peuvent accélérer ce processus, la nature plus «aléatoire» du choc COVID-19 et la réponse politique qui a donné la priorité à la préservation (sur la réallocation) soulève la question de l'effet de la réallocation des emplois sur la productivité pendant la pandémie. Notre analyse basée sur de nouvelles données sur l'emploi à haute fréquence pour l'Australie montre que la réallocation des emplois (et la sortie d'entreprise) est restée solidement liée à la productivité des entreprises en 2020. La plus grande résilience des entreprises à haute productivité est significative, étant donné que des faillites massives de telles entreprises - et la destruction associée du capital intangible spécifique à l'entreprise - auraient eu des effets négatifs à long terme importants. II s'avère que la nature temporaire du programme australien de maintien dans l'emploi (JobKeeper) a apporté une contribution positive importante (et surprenante) à ce processus, avec des conséquences importantes sur la productivité agrégée. Mais le régime semble avoir créé de plus en plus de distorsions au fil du temps, justifiant son retrait en temps opportun - au moins pour des raisons de productivité.

Classification JEL: E24, E32, J63, O4.

Mots Clés: COVID-19, productivité, réallocation, récessions. 


\section{Table of contents}

COVID-19 and Productivity-Enhancing Reallocation in Australia: Real-time evidence from Single Touch Payroll

1. Introduction

2. COVID-19, Reallocation and Productivity

2.1. Why focus on reallocation?

2.2. COVID-19: Cleansing or Scarring?

3. High-frequency firm-level data 11

3.1. Single touch payroll 12

3.2. Firm performance over the pandemic 12

4. COVID-19 and productivity-enhancing reallocation dynamics 14

4.1. Baseline model $\quad 14$

4.2. Empirical results $\quad 15$

4.3. Robustness 18

5. Productivity, Reallocation and JobKeeper 18

5.1. Empirical framework 18

5.2. Productivity, reallocation and JobKeeper 20

6. Which firms took-up the JobKeeper subsidy?

6.1. Empirical framework 23

6.2. Empirical results $\quad 23$

$\begin{array}{ll}\text { 7. Aggregate implications } & 26\end{array}$

$\begin{array}{ll}\text { 8. Conclusion } & 28\end{array}$

References $\quad 29$

Annex A. Additional Results 33

$\begin{array}{ll}\text { Annex B. Robustness tests } & 40\end{array}$

\section{Tables}

Table 1. Firm-level growth and exit responsiveness to productivity: baseline results 16

Table 2. Firm-level growth responsiveness to productivity: role of JobKeeper 21

Table 3. The JobKeeper Scheme, firm-level productivity and financial constraints 24

Table A.1. Distribution of jobs by division in STP $\quad 35$

$\begin{array}{ll}\text { Table A.2. Summary statistics } & 35\end{array}$

Table A.3. Firm-level growth and exit responsiveness to productivity: role of firm size 38

Table A.4. Firm-level growth and exit responsiveness to productivity: role of firm age 38

Table B.1. Firm-level growth and exit responsiveness to productivity: turnover-based productivity 40

Table B.2. Firm-level growth and exit responsiveness to productivity: alternate headcount metrics 40 


\section{Figures}

Figure 1. Employment in Australia since March 2020

Figure 2. Job reallocation since the onset of the pandemic

Figure 3. Difference in performance between high and low productivity firms: long change 17

Figure 4. Difference in performance between high and low productivity firms: monthly change 18

Figure 5. Productivity-enhancing reallocation varied across labour markets according to JobKeeper coverage 22

Figure 6. JobKeeper take-up, firm productivity and vulnerability to the shock

Figure 7. JobKeeper shielded more productive firms but less so over time 26

Figure 8. Aggregate implications 28

Figure A.1. Payroll Jobs by Division $\quad 36$

Figure A.2. Widespread heterogeneity in firm performance $\quad 37$

Figure A.3. Difference in performance between high and low productivity firms: by industry 39

\section{Boxes}

Box 1. Australia's Job Retention Scheme - JobKeeper 8

Box 2. Recessions and the reallocation process: cleansing or scarring? 11

Box A.1. The COVID-19 Shock and Potential Output 33

Box A.2. Productivity-enhancing reallocation 34 


\title{
COVID-19 and Productivity-Enhancing Reallocation in Australia: Real-time evidence from Single Touch Payroll
}

\author{
Dan Andrews, Elif Bahar and Jonathan Hambur ${ }^{1}$
}

\section{Introduction}

1. As the vaccine rollout gains traction and economic recovery takes hold, attention will invariably shift to the pandemic's impact on potential output. While the COVID-19 shock could impart lasting scars if it reduced educational attainment (via disruptions to schools) or the scope for knowledge spillovers (via less international worker mobility), there could be productivity benefits if the pandemic forced firms to make overdue investments in digitalisation and organisational practices. While these channels are likely relevant, they are not yet directly observable and act over long horizons. But the emergence of real-time data sources provides an opportunity to get a timely gauge on the pandemic's impact on productivity-enhancing reallocation - the tendency for more productive firms to expand and less productive firms to contract (or exit). This is significant if COVID-19 implies a reallocation shock - especially if new habits form from pandemic-induced experimentation with novel modes of business, work and consumption (Barrero et al 2020) - but the debate has so far lacked a clear link with productivity.

2. The nature of economic downturns can fundamentally alter the extent of productivity-enhancing reallocation. The "cleansing" hypothesis posits that recessions can accelerate productivity-enhancing reallocation by lowering the opportunity costs of reallocation - and providing a fertile breeding ground for firm restructuring - assuming that markets continue to select (scrap) the most (least) productive firms (Schumpeter 1939). But recessions can distort reallocation dynamics, if an impaired financial sector leads reallocation to be driven more by credit constraints than underlying firm productivity. This could result in the premature shakeout of productive but financially fragile firms, and the destruction of valuable intangible capital (which is necessarily lost with business closure). The pandemic could provide a further twist on the cleansing hypothesis if workforce adjustments and business survival became detached from firm productivity owing to the broad-based nature of lockdowns, and crisis phase policies (i.e. job retention schemes) that prioritised preservation (over reallocation) to address other policy aims. But timely evidence on the impact of the pandemic on productivity-enhancing reallocation dynamics remains scarce.

\footnotetext{
${ }^{1}$ The corresponding author is Dan Andrews (Dan.Andrews@oecd.org) from the OECD Economics Department. Elif Bahar (elif.bahar@treasury.gov.au) and Jonathan Hambur (jonathan.hambur@treasury.gov.au) work in the Macroeconomic Group of Australian Treasury. The paper has benefited from excellent comments from by Luiz de Mello, Alain de Serres, Ben Conigrave, Michael Koelle, Mathilde Limbergere and seminar participants at the Australian Treasury and Reserve Bank of Australia. Elsa Cruz de Cisneros and Sarah Michelson (OECD, Economics Department) provided editorial support. The opinions expressed are those of the authors and do not necessarily reflect the views of the Australian Government or the OECD.
} 
3. Accordingly, this paper explores how the COVID-19 shock, as well as Australia's wage subsidy scheme ("JobKeeper"), shaped productivity-enhancing reallocation. We utilise novel high frequency administrative tax data on employment outcomes from Single Touch Payroll collected by the Australian Tax Office (ATO), merged with firm-level measures of labour productivity, financial constraints and other relevant firm characteristics from ATO Business Income Tax (BIT) data for 2018/19. We then model dynamic allocative efficiency by estimating the responsiveness of firm-level employment changes (and exit) since March 2020 to (pre-pandemic) labour productivity, controlling for any differences in the shock across state-by-industry, and firm size and age classes. Andrews and Hansell (2021) show that the strong connection between (within-industry) labour reallocation and firm-level productivity significantly boosted Australian productivity growth over 2002-2016. But did this remain the case following the onset of the pandemic?

4. We find that reallocation remained connected to firm productivity over the course of the pandemic, despite a decline in the overall rate of reallocation (i.e. hiring plus separations). Between March and December 2020, the implied difference in employment growth between a high productivity firm - i.e. one with labour productivity (LP) one standard deviation above the industry mean - and a low productivity firm - i.e. one with LP one standard deviation below the industry mean - was 6.5 percentage points. Similarly, a low productivity firm was on average 3.75 percentage points more likely to exit than a high productivity firm. These results suggest that high productivity firms were more resilient to the shock. Consistent with the cleansing hypothesis, the estimated reallocation-productivity link was stronger: $i$ ) amongst smaller firms, which were more exposed to the shock; ii) during the first wave of the pandemic when the national economic impacts were largest (April-May), particularly in hard-hit sectors; and iii) in Victoria's second wave (July-August).

5. That the reallocation-productivity link remained intact is perhaps surprising, given the scale of the JobKeeper Payment - the largest one-off fiscal measure in Australia's history - which supported more than 3.8 million individuals and over one million organisations from March to September 2020 (see Box 1). The JobKeeper scheme aimed to support household incomes, reduce uncertainty and temporarily shield firm-specific capital by maintaining the connection between workers and firms (in order "to build a bridge between the pre and post pandemic economies"; Lowe 2020). But a key risk was that JobKeeper could result in 'zombification' if it delayed the restructuring of unproductive firms that would have downsized or exited in absence of the virus. If realised, this could crowded out growth opportunities for more productive firms, reminiscent of the rise of zombie firms in Europe (Adalet McGowan et al, 2018).

6. While overall job reallocation declined sharply following the announcement of the JobKeeper scheme on 30 March 2020 (Australian Treasury 2020), its impact on the reallocation-productivity link is unclear. Thus, we to test if the reallocation-productivity link varied with the share of workers receiving the JobKeeper subsidy at the local labour market level, after controlling for the size of the local economic shock. On average over the life of the scheme, we find that productivity-enhancing reallocation was stronger in those local labour markets that had a higher proportion of workforce in receipt of JobKeeper.

7. This latter result is largely driven by the early stage of the crisis when economic conditions were more depressed and uncertainty was high. But the policy appears to have become more distortive over time. To illustrate, we examine what occurred when the Payment began being phased out from September 2020, when the first phase of the JobKeeper scheme (henceforth JobKeeper 1.0) ended and firms had to requalify for the scheme's second stage (henceforth JobKeeper 2.0). In those local labour markets where a large amount of the workforce exited the scheme, more labour flowed towards high productivity firms (i.e. there was a stronger reallocation-productivity link). This suggests that, if the payment had not been phased out, this productive reallocation may not have occurred, as there was virtually no evidence of productivity-enhancing labour reallocation (from August to November) in those markets where workforce transitions off the scheme were minimal. Put another way, the policy appears to have been leading to a degree of distortive labour hoarding as the economy recovered. And when the policy was wound down, this released labour to be reallocated to more productive uses. 


\section{8 | ECO/WKP(2021)28}

8. The shift in policy from supportive to potentially distortive over time is consistent with the (preshock) characteristics of the firms that took-up the subsidy across the two policy regimes. Under JobKeeper 1.0, more productive firms - and especially financially constrained ones - were more likely to take-up the subsidy, thus helping to prevent scarring effects that can arise from the premature exit of dynamic firms. But JobKeeper 2.0, was more likely to subsidise less productive firms during pandemic-induced trading disruptions, suggesting that policy became more distortive over time as the economy recovered. These results are consistent with firm dynamics models which predict that in the face of an uncertainty shock (i.e. like COVID-19) - and some fixed costs of operation - high productivity firms are likely to take on the cost and operate, given the higher expected value of doing so. But as the economy recovered, it was only the worse performing firms - as well as the sectors still affected by restrictions - that still qualified. Put differently, the early stages of the program were characterised by broad uptake, including by high productivity firms. As the economy recovered, these firms no longer required that support, generally leaving less productive firms on the program.

\section{Box 1. Australia's Job Retention Scheme - JobKeeper}

In March 2020, the Australian government announced JobKeeper - Australia's largest job retention scheme in history. The policy supported over 3.8 million individuals and 1 million businesses, and aimed to: I) maintain links between firms and workers to facilitate a quick economic recovery and limit economic scarring; ii) provide income support, complementing increased generosity in welfare payments; and iii) decrease uncertainty by ensuring a wage 'floor'.

The scheme provided a flat rate AUD1500 per fortnight subsidy to be paid to any eligible employees, and one eligible business participant (e.g. owner manager) in a business. Eligible employees included all permanent staff, and any long-term casual staff (employed regularly for over one year) and were not dependent. Eligibility for the first stage of the scheme was dependent on having the reasonable expectation that the firm would experience a year-on-year decline in revenue generally of more than 30 per cent for at least one month. By qualifying once, firms qualified for the full 6 month period of the initial policy (April to September 2020). At the time the JobKeeper Payment was announced, it was expected that Australia would face significant restrictions for an extended period meaning a high share of businesses were eligible.

In July 2020, the Australian Government announced that it would extend the scheme for another six months, in two 3-month extensions (October to December 2020, and January to March 2021). But this "second phase" had a materially different design. Eligibility for each extension would require the business to re-qualify by demonstrating an actual year-on-year decline in quarterly revenue, generally of at least 30 per cent in the previous quarter. The payment rates were lowered, and a tiering system was introduced based on the employees' 'normal' hours.

9. The greater resilience of high productivity firms to the pandemic raised aggregate labour productivity by an estimated $41 / 4$ to $51 / 2$ per cent, relative to a counterfactual where the pandemic completely severed the reallocation-productivity link (abstracting from changes in firm-level productivity). We estimate that about one-half of this aggregate gain $\left(\sim 2 \frac{3}{4}\right.$ per cent) can be accounted for by the introduction of JobKeeper 1.0, and more specifically its tendency to disproportionately shield more productive firms. Had policymakers not began to phase-out the JobKeeper scheme from late September 2020, and the economy not experienced an additional 'burst of efficient reallocation, aggregate labour productivity would have been an estimated 2 per cent lower by November 2020, reflecting the increasing allocative distortions of the policy. While this drag may have been temporary (as some reallocation would have invariably occurred when the scheme ended), the winding-up of the JobKeeper scheme on 28 March 2021 appears justified on productivity grounds at least - especially in light of the macroeconomic recovery.

10. Our results suggest that job retention schemes can be an effective crisis tool. Indeed, without the JobKeeper scheme, there could have been more of an indiscriminate shakeout of high productivity - and 
especially productive but liquidity constrained - firms, risking significant scars on Australian productivity and lowering potential output. But our findings underscore the need for job retention schemes to be temporary and for their design to evolve as there is a fine line between hibernation and zombification. Of course, this risk should be weighed against the other benefits (e.g. decreasing uncertainty) of such policies.

11. Our contribution is threefold. First, we supply novel real-time insights - based on high quality administrative tax data - on the impact of the pandemic on productivity-enhancing reallocation. This is significant given that the seminal paper on the impact of the Great Recession on productivity-enhancing reallocation first appeared - in working paper version - some six years after Lehman Brothers collapsed (Foster et al., 2014). Second, we provide the first systematic real-time evidence on the financial characteristics of firms that participate in job retention schemes and consequences for aggregate productivity. Third, we contribute to the broader debate on job retention schemes, and specifically the trade-off between short-term protection and the allocative distortions that may materialise over the longer horizons.

12. The next section explores how recessions - and especially the pandemic - may impact the reallocation process while Section 3 describes the real-time data and presents some preliminary descriptive evidence on firm performance since the onset of the pandemic. Section 4 presents new evidence on the evolution of productivity-enhancing reallocation dynamics since the onset of the pandemic. Sections 5-7 then explore the potential impact of the JobKeeper scheme on the process and the implications for aggregate productivity. The final section draws some key policy implications.

\section{COVID-19, Reallocation and Productivity}

\subsection{Why focus on reallocation?}

13. As discussed in Box A1 of Annex A, there various channels through which the pandemic could affect potential output, spanning labour quality (e.g. via schooling disruptions), capital deepening (e.g. accelerated ICT investment) and total factor productivity (e.g. business experimentation and reallocation). Since many of these channels relate to forces that are not yet directly observable or act over long horizons - e.g. the human capital impacts will not be known for decades - we aim to shed real-time evidence on the within-industry reallocation channel.

14. While COVID-19 has been characterised as a reallocation shock (Barrero et al 2020), the debate has lacked a link with productivity, which as discussed below is crucial. We focus on the labour reallocation channel by exploring how firm-level employment changes (and exit) since the onset of the pandemic are correlated with a firm's pre-shock level of labour productivity. Given its strong theoretical and empirical basis, this approach is likely to broadly be indicative of the pandemic's structural impulse on TFP via the reallocation channel. Furthermore, given that it does not require data on firm-level productivity during the crisis - which is notoriously volatile - it carries clear advantages from a measurement perspective.

15. Market economies are characterised by a resource reallocation process that has two key dimensions.

1. The rate of reallocation is high, with headline economic statistics concealing an intense churning of jobs and firms, as successful market activities are sorted from unsuccessful ones. Across the OECD, gross job creation and job destruction rates averaged $12 \%$ and $10 \%$ over 2004-2007, with these figures reversing as the crisis took hold (Criscuolo, Gal and Menon 2014). Firm entry (exit) typically accounts for one-quarter (one-third) of gross job creation (destruction).

2. This reallocation process is strongly linked to firm-level productivity. As outlined in Box A2, evidence shows that: $i$ ) high productivity firms are more likely to expand and low productivity firms 
more likely contract and exit (Decker et al., 2020)룰 and ii) this process of (within-industry) resource reallocation materially boosts aggregate productivity growth.

16. It is crucial that the reallocation process is productivity-enhancing as it also entails costs - via job destruction - which are politically salient. In many OECD countries, however, the productivity slowdown has been underpinned by a decline in the overall rate of job reallocation, as well as a weaker reallocationproductivity link (Decker et al, 2020). For example, the declining (within-industry) reallocation of labour from less productive to more productive firms can account for one-quarter Australia's productivity slowdown after 2012 (Andrews and Hansell (2021). It is against this background that the question of how the COVID-19 shock will affect productivity - via the reallocation channel - looms large.

\subsection{COVID-19: Cleansing or Scarring?}

17. The impact of recessions on productivity-enhancing reallocation remains an open question, with debate centring on the extent to which recessions unleash cleansing or scarring dynamics (see Box 2). But the impact of the pandemic on this process is even more theoretically ambiguous for a range of reasons.

18. On the one hand, the COVID-19 shock may have severely disrupted the typical reallocation process. In this view, the pandemic was a health shock that was exogenous to pre-crisis firm performance and the collapse in mobility that followed - a function of both fear and arbitrary lockdowns - affected all firms, regardless of their productivity. This was reinforced by a crisis economic policy response that prioritised preservation (or hibernation) via job retention schemes and various measures to shield firm finances and prevent foreclosure. These forces had two consequences. First, the job reallocation rate fell significantly, as job destruction was effectively curbed while there was limited scope for job creation. Second, the reallocation-productivity link was likely diminished, if not completely severed.

19. An alternative view posits that the reallocation-productivity link remained - even if the overall rate of reallocation fell - as the nature of the shock accentuated the importance of firm capabilities and organisational capital. COVID-19 forced a wave of experimentation with "novel modes of business, work, consumption and communication" and accelerated digital transformation (Barrero et al 2020). High productivity firms - due to their superior managerial practices (Bloom and Van Reenen, 2007) - could more effectively accommodate teleworking and nimbly adapt their business models to social distancing, which enabled them to capitalise on new growth opportunities. Better managed firms may have also been more able to capitalise on the range of policy support measures available.

20. Evidence on the impact of the pandemic on productivity-enhancing reallocation is scarce, partly due to the fact that few real time datasets contain information on firm-level productivity. That said, the limited evidence is broadly consistent with the idea that reallocation declined but remained connected to productivity:

- Bloom et al (2021) exploit survey data from the Decision Maker Panel and find that hours worked fell more sharply in 2020-Q2 for firms that had lower productivity (over 2017-2019). While this partly

\footnotetext{
2 These empirical studies take their structure from: $i$ ) the canonical models of firm dynamics whereby idiosyncratic shocks to productivity, demand, and costs impact the growth and survival of heterogeneous firms (Jovanovic 1982; Hopenhayn1992; Hopenhayn and Rogerson 1993; Ericson and Pakes 1995); and ii) the adjustment cost literature for employment dynamics, which predicts that, conditional on initial size, plants with positive productivity shocks are more likely to grow (Cooper, Haltiwanger, and Willis 2007).
} 
reflects the fact that the pandemic hit lower productivity sectors harder, the connection between the contraction of hours worked and firm productivity is also observed within sectors. ${ }^{3}$

- Evidence from France and Japan shows that the number of firms filing for bankruptcy fell during 2020 but the factors that predicted firm failures in 2019 - primarily low productivity and debt - were at work in a similar way in 2020 (Cros, Epaulard and Martin, 2021; Hong and Saito, 2021).

- Finally, better managed firms in Italy experienced smaller declines in expected sales during the post-lockdown period, which may partly reflect their ability to provide effective monitoring and incentive structures to support teleworking (Lamorgese et al, 2021).

\section{Box 2. Recessions and the reallocation process: cleansing or scarring?}

The process of reallocation can vary with the economic cycle. On the one hand, recessions can provide a fertile breeding ground for restructuring if markets select (scrap) the most (least) productive firms yielding the so-called cleansing effects (Caballero \& Hammour 1994). Recessionary episodes in United States from the 1940 s to the early 2000 s generally displayed such cleansing dynamics. 1 Reallocation accelerated - as the rise in job destruction more than offset the decline in job creation - and was strongly linked to productivity, with job destruction and exit concentrated in lower productivity business units.

But recessions may be less benign due to sullying or scarring effects. This can arise if fewer high quality job matches are created (Barlevy 2002) or if credit frictions lead productive but financially fragile firms to disproportionately contract or exit (Barlevy 2003). While recent evidence suggests that the latter may not be sufficient to overturn the cleansing effect (Osotimehin and Pappada 2015), it is notable that reallocation fell during the Great Recession - with the decline in job creation outweighing the rise in job destruction - and there was a weaker link with productivity, especially amongst young firms (Foster, Grim and Haltiwanger, 2014, 2016). Financial crises might impart scars if they reduce entrepreneurial finance (Buera and Moll, 2015) and disrupt the fragile post-entry learning-by-doing process (Ouyang, 2009), leading to a "lost generation" of firms (Sedláček, 2020). Even so, successful start-ups have emerged during downturns testament to the ability of young firms to nimbly respond to changing market conditions (Calvino, Criscuolo and Verlhac, 2020).2

Despite this mixed evidence, it is vital that reallocation remains connected to firm productivity. By accelerating job destruction and firm exit, recessions can lead to losses of job-specific capital and organisational capital - both internal (i.e. tacit knowledge) and external (i.e. supply chain connections) to the firm. These costs are compounded when the process of downsizing and exit is not driven by productivity, as there is no scope for productivity-enhancing reallocation towards more efficient producers on the other side (Syverson 2020).

${ }^{1}$ See: Davis and Haltiwanger (1990, 1992 and 1999); Davis, Faberman, and Haltiwanger (2006, 2012); Foster, Haltiwanger, and Krizan (2001); and Davis, Haltiwanger, and Schuh (1996).

${ }^{2}$ For example, Dropbox, Uber, Airbnb, WhatsApp, Groupon, and Pinterest were all founded during or just after the Global Financial Crisis, while Alibaba's Taobao that was founded during the SARS outbreak in China in 2003.

\section{High-frequency firm-level data}

21. If history is any guide, evidence on the impact of the pandemic on reallocation and productivity is still many years away. Lengthy time lags that characterise the release of suitable microdata sources, with (BLS) establishment-level and (Census Bureau) firm-level data on business deaths in the United States

\footnotetext{
${ }^{3}$ Bartik et al (2020) speculates that the pandemic may have engendered cleansing effects in the United States on the basis that firms with weak sales growth in 2019 were more likely to shutdown at the peak of the first wave of the pandemic and subsequently less likely to re-open during the "recovery".
} 
during mid-2020 not slated for release until late 2021 and 2023 respectively (Crane et al, 2020). But we have a unique opportunity to shed light on this question by exploiting real time administrative data from Single Touch Payroll (STP), collected by the Australian Tax Office (ATO).

\subsection{Single touch payroll}

22. The ATO receives payroll data from STP-enabled firms when the firm runs its payroll. ${ }^{4}$ This yields high frequency data on jobs and wages which we merge with annual Business Income Tax data (from 2018/19) containing (value added and turnover-based) measures of labour productivity, financial health (i.e. liquidity) and firm characteristics (i.e. firm size, age and industry). Crucially, the dataset also contains flags for whether a firm was a recipient of JobKeeper - Australia's Job Retention Scheme.

23. STP has broad-based coverage across industries, and we consider all States, as well as the Australian Capital Territory and the Northern Territory (Table A.1). Employers with 20 or more employees (large employers) commenced transition to STP reporting on 1 July 2018 , with approximately $99 \%$ of large employers reporting through STP as at December 2020. ${ }^{5}$ Employers with less than 20 employees (small employers) began transitioning to STP on 1 July 2019. This delayed transition coupled with a range of reporting concessions that the ATO made available to some small firms ${ }^{6}$ meant that approximately $77 \%$ of small employers were reporting through STP as at the beginning of September 2020. Payroll jobs reported via STP exclude owner managers of unincorporated enterprises. ${ }^{7}$ Is it reported on a jobs basis, instead of a heads basis like standard labour force statistics. Unfortunately, the dataset does not include hours, precluding analysis on this margin. However, Andrews, Charlton and Moore (2021) considers this using a smaller data set based on Xero accounting software.

24. As discussed below, our econometric framework - through the inclusion of industry, state and firm size fixed effects - allows us to control for any minor differences in coverage, by focusing on firm dynamics within cells (i.e. industry, and firm size classes, in a given state). ${ }^{8} \mathrm{We}$ implement a range of data cleaning techniques that are customary in the literature: $i$ ) including winsorising key economic variables - such as labour productivity - at the top $1 \%$ and bottom $1 \%$ of the within-industry distribution; ii) excluding the government and not-for-profit sectors, as well as non-employing firms; iii) employment and labour productivity data for all subsidiaries firms in a consolidated industry is summed, and for some variables (e.g. industry, age), information is taken from the largest (by income) firm in the consolidation.

\subsection{Firm performance over the pandemic}

25. Figure 1 plots the evolution of STP jobs since the week ending 14 March 2020. Panel A shows total STP jobs fell sharply from March and troughed in mid-April, roughly a fortnight after Australia's job retention scheme - JobKeeper - was announced (on 29 March). Employment then recovers - retracing almost one-half of the initial decline within two months - before a COVID-19 outbreak in the state of Victoria

\footnotetext{
${ }^{4} \mathrm{~A}$ payroll job is a relationship between an employee and their employing enterprise, where the employee is paid in the reference week through STP-enabled payroll or accounting software and reported to the ATO. Where an employee is paid other than weekly, the established payment pattern is used to include payroll jobs paid in weeks outside the reference week.

${ }^{5}$ Payroll reporting via STP is still relatively new and some employers have been granted concessions to enable a longer transition period to mandatory STP reporting.

${ }^{6}$ Reporting concessions were made available to small firms if they: $i$ ) employ family members or other 'closely held' payees; ii) are micro employers with one to four employees; iii), employ intermittent or seasonal workers; or iv) do not have access to a reliable internet connection.

7 Table A.2 contains summary statistics for our sample.

8 That said, we still exclude non-employing firms, which accounted for a large share of firms on JobKeeper, though a lower share of payments. Whether or not the results, or even conceptual frameworks, extend to these firms is unclear.
} 
in late June weighs on the national recovery. By November 2020, however, national employment has returned to around pre-shock levels and, looking through the seasonal volatility at the turn of the year, subsequently hovers around that level.

26. Aggregate movements conceal significant heterogeneity. As is the case in other OECD countries, the decline in employment is concentrated in those hard-hit sectors centred on in-person services, with STP jobs in Accommodation \& Food Services, for example, declining by around 35\% between early March and mid-April (Figure A.1 of Annex A). The shock also hits smaller firms harder, with the decline in STP jobs in SMEs more than twice as large as that for larger firms (200+ employees) through March-April 2020 (Figure 1, Panel B). Given that larger firms are more productive than SMEs in Australia (Andrews and Hansell, 2021), this provides suggestive evidence of cleansing effects, but it could also reflect the sectoral composition of the shock if smaller firms are more prevalent in hard-hit sectors.

Figure 1. Employment in Australia since March 2020

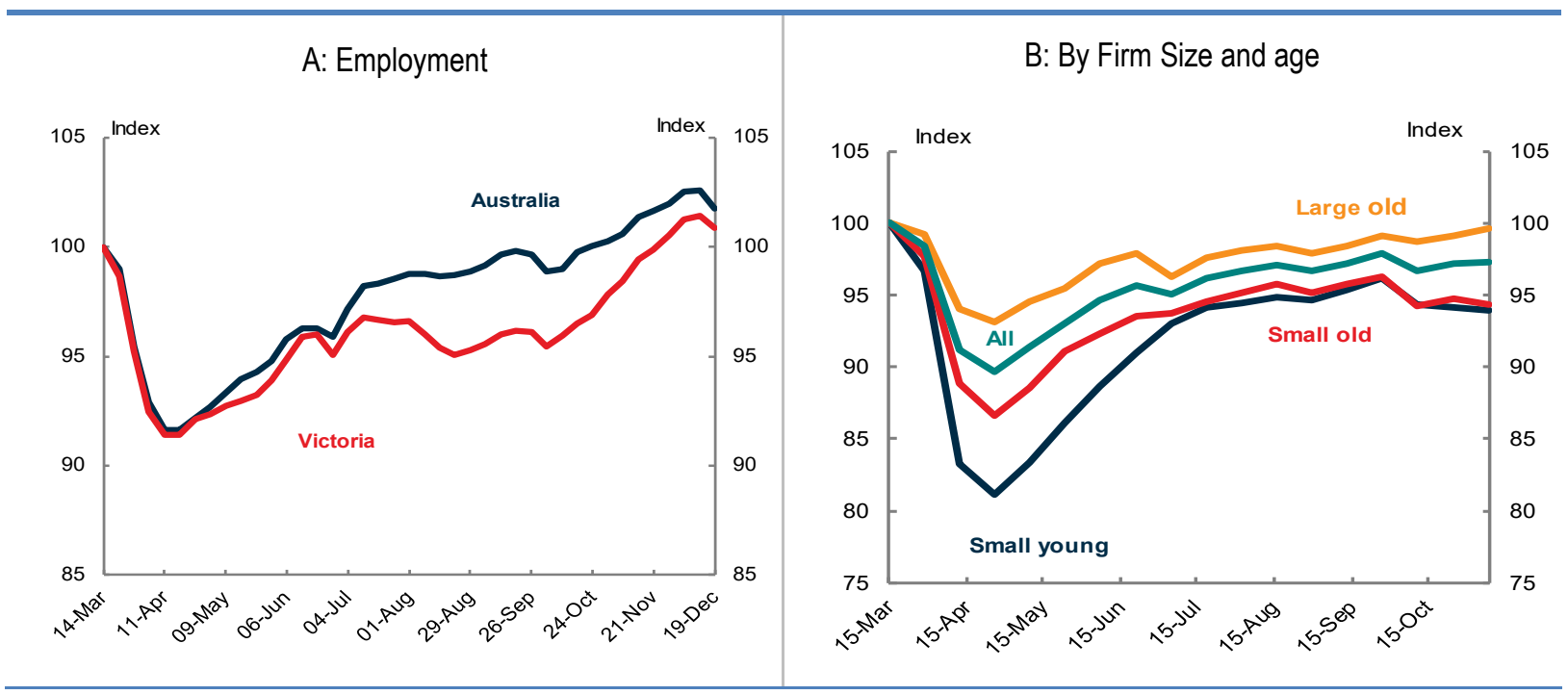

Note: All series indexed to week ending 14 March 2020. In panel B, small firm is 1-199 employees. Young is age 5 or below. Source: Authors' calculation based on ABS Weekly Payrolls (STP). Authors' calculations based on STP microdata.

27. As is now well established, the labour market shock was buffered by the use of job retention schemes (JRS), which preserved the connection between workers and firms - despite a sharp pandemicinduced economic downturn - with many workers on drastically reduced hours. ${ }^{9} \mathrm{JRS}$ were an effective crisis tool as they aimed to curtail job destruction. This can be seen from the sharp decline in job separations following the announcement of the JobKeeper scheme in late March (Figure 2), especially amongst subsidised firms who were generally hit harder by the shock and experienced a spike in separations (Panel B). Moreover, the application of JRS implied a significant reduction in job reallocation (creation + destruction) rates following the onset of the pandemic. Thus, JRS need to be temporary to ensure that they do not stifle job creation and the necessary reallocation of resources that underpins recovery from recessions.

28. While the pandemic was associated with a fall in the overall rate of job reallocation, it did not completely freeze creative destruction. Even after JobKeeper was announced, a non-trivial share of firms

\footnotetext{
${ }^{9}$ Similar to other countries, Labour Force Survey (LFS) data shows that average hours worked falls much further than (a heads measure of) employment in Australia. However, the LFS contains no data on the firm so it is not possible to explore how hours worked changes across the distribution of firm productivity.
} 
were still shedding workers and many firms were still growing over 2020 (Figure A.2, Panel A in Annex A). This diversity is significant in light of the widespread heterogeneity in firm productivity within narrowlydefined industries (Figure A.2, Panel B; Syverson 2011), which creates scope for growth-enhancing resource reallocation towards more productive firms. ${ }^{10}$ The rest of the paper explores how firm-level workforce adjustments were connected to a firm's rank in the (within-industry) labour productivity distribution.

\section{Figure 2. Job reallocation since the onset of the pandemic}

Index, 1 March 2020=100

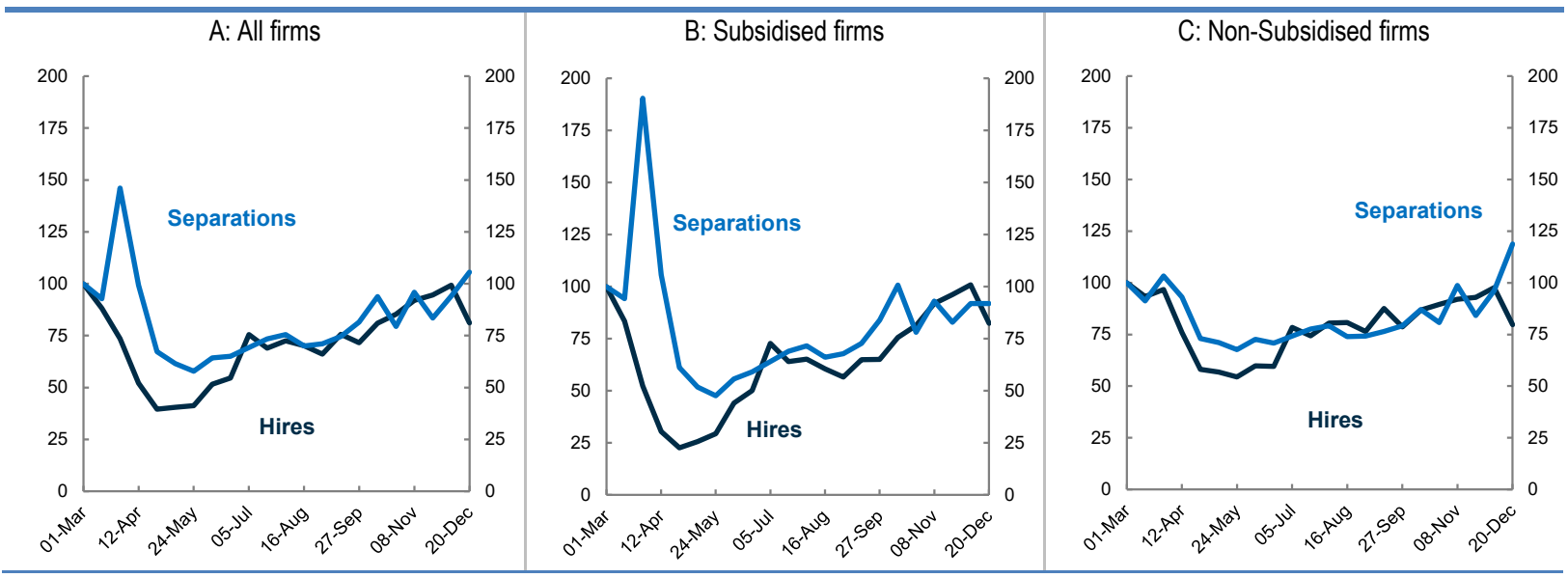

Note: Figure presents fortnightly time series, indexed to equal 100 in the fortnight ending 1 March 2020. Hires and separations are based on start and cease dates for a worker's employment relationship with a business. These include relationships with zero pay, which is one reason why the separations index can remain above the hiring index, despite paid payroll job levels having stabilised — an employment relationship can formally end sometime after paid work has ceased.

Source: Authors' calculation based on STP data.

\section{COVID-19 and productivity-enhancing reallocation dynamics}

\subsection{Baseline model}

29. As discussed above, there is much evidence that conditional on initial firm size, high-productivity firms are more likely to grow and low-productivity firms are more likely contract and exit. We apply the workhorse econometric model from this literature to STP high frequency microdata to explore the potential impact of the pandemic on the (within industry) connection between job reallocation and productivity in Australia.

30. More formally, this starts with the construction of the dependent variable, which is defined as the change in firm-level employment divided by the average employment across both periods following Davis, Haltiwanger and Schuh (1996):

$$
E_{i, t}=\frac{N_{i, t}-N_{i, t-1}}{\frac{N_{i, t}+N_{i, t-1}}{2}} * 100
$$

\footnotetext{
${ }^{10}$ Within our sample a firm at the $75^{\text {th }}$ percentile of the within-industry labour productivity distribution produces around two times as much revenue per worker as a firm at the $25^{\text {th }}$ percentile of the distribution. See Figure A.4, Panel B.
} 
where $\mathrm{E}$ is employment growth rate of firm $i$ to period $t$, and $\mathrm{N}$ is number of employees at firm $i$ in period $t$, or $t-1$ (March 2020, the base month). This measure is bounded between -200 and 200 and it is a second order approximation of the log difference for growth rates around zero. Further it can accommodate growth exiting firms, in which case the function takes a value of -200 (exit).

31. We then estimate the following baseline equation:

$$
\Delta E_{i s r}=\alpha+\beta L P_{i s r}+X_{i s r}+\rho_{s r}+\varepsilon_{i s r}
$$

Where: $\mathrm{E}$ is cumulative change in employment between March 2020 and subsequent points (for main results December 2020; see equation 1) or firm exit probability for firm $i$, (4 digit) industry s, and state $r$. LP is the log level of firm-level labour productivity in 2018/19, computed as either value added (or turnover) per worker. ${ }^{11}$ We also estimate a more flexible specification with dummy variables corresponding to the firm's quartile in the (within-industry) labour productivity distribution (in place of the log level of LP), with the lowest productivity quartile the base case (and its dummy excluded). $X$ includes controls for firm size classes based on 2018/19 employment ( $<5,5-19,20-49,50-199,200+$ employees) and firm age classes $(<2,3-5,6-10,11-19,20+$ years $)$. Finally, $\rho$ contains a battery of fixed effects at the industry and state level. Conceptually, industry fixed effects sweep-out differences in average industry performance at the national level (i.e. hospitality was hit harder by the pandemic than food retailing) while state fixed effects controls for average differences in state performance (i.e. Victoria was hit harder than Western Australia). In practice, we include interacted state-industry fixed effects, which allows us to control for the fact that the pandemic hit firms harder in the hospitality sector in Victoria than in NSW. Standard errors are clustered at the state*industry level.

32. If $\beta>0$, then looking within state-industry cells and holding firm size and age constant, more productive firms are more likely to expand and less productive firms are more likely shed labour, suggesting that reallocation is productivity-enhancing. It also implies that more productive firms were more resilient to the COVID-19 shock. We explore various sources of heterogeneity in the reallocation-productivity link. First, we test if the strength of the link varies across states by interacting LP with Victoria dummy. Second, we explore differences across industries by interacting LP with a dummy variable for those industries centred on in-person services - that were hit particularly hard by the pandemic. Third, we test if the reallocation-productivity link is stronger for smaller versus larger firms and younger versus older firms, by interacting LP with firm size and age dummies.

\subsection{Empirical results}

33. Table 1 (Panel A) shows estimates from regressions of the cumulative log change in firm-level employment between March and December 2020 (Column 1) and firm exit probability (Column 3) on the log level of firm-level labour productivity in 2018/19. The coefficient on productivity is positive and statistically significant at the $1 \%$ level, suggesting that on average over the course of 2020 , high productivity firms were more likely to expand and survive, while low productivity firms were more likely to contract or exit. Moreover, the more flexible specification in Columns 2 and 4 shows that firm-level employment performance and survival was strongest (weakest) in the highest (lowest) productivity quartile, and

\footnotetext{
11 Some studies utilise multi-factor productivity (MFP) but this is not possible to estimate due to the lack of capital stock data. Studies show that estimation results of Equation [2] are insensitive to the choice of productivity measure, reflecting the high correlation within industries between firm-level labour productivity and MFP (Decker et al., 2018). While it is customary to measure labour productivity as value-added per worker, we also calculate a turnover-based measure as this allows for the inclusion of the small - but non-trivial - share of firms that record negative value-added, which are necessarily dropped when taking the logarithm of value-added per worker. In any case, the (within industry) correlation between turnover and value-added based labour productivity is high (Andrews and Hansell, 2021).
} 
increasing in a monotonic fashion across the distribution. Thus, churn and productivity remained connected and thus productivity-enhancing over the pandemic, despite crisis phase policies that prioritised preservation over reallocation. Put differently, high productivity firms were more resilient to the shock. ${ }^{12}$

34. These differences in firm performance are economically significant and carry important aggregate implications. Between March-December 2020, the implied difference in employment growth between a high productivity firm - i.e. one with LP one standard deviation above the industry mean - and a low productivity firm - i.e. one with LP one standard deviation below the industry mean - was 6.5 percentage points (Figure 3 Panel A). Similarly, the implied exit probability for a low productivity firm was on average 3.75 percentage points higher than for a high productivity firm (Figure 3 Panel B).

\section{Table 1. Firm-level growth and exit responsiveness to productivity: baseline results}

Dependent variable: change in firm-level employment between March and December 2020

\begin{tabular}{|c|c|c|c|c|}
\hline & \multicolumn{2}{|c|}{ A: Change in employment } & \multicolumn{2}{|c|}{ B: Probability of firm exit } \\
\hline & (1) & (2) & (3) & (4) \\
\hline Labour productivity $_{\text {isr }}$ & $\begin{array}{c}2.568^{\star * *} \\
(0.160)\end{array}$ & & $\begin{array}{c}-0.0149^{* * *} \\
(0.00100)\end{array}$ & \\
\hline Labour productivityQ2 $2_{\text {isr }}$ & & $\begin{array}{c}4.691^{* * *} \\
(0.372)\end{array}$ & & $\begin{array}{c}-0.0271^{* * *} \\
(0.00163)\end{array}$ \\
\hline Labour productivityQ $3_{\text {isr }}$ & & $\begin{array}{c}6.589^{* * *} \\
(0.373)\end{array}$ & & $\begin{array}{c}-0.0392^{* * *} \\
(0.00220)\end{array}$ \\
\hline Labour productivity $Q 4_{\text {isr }}$ & & $\begin{array}{c}7.241^{* * *} \\
(0.521)\end{array}$ & & $\begin{array}{c}-0.0413^{* * *} \\
(0.00305)\end{array}$ \\
\hline Constant & $\begin{array}{c}-45.36^{\star * *} \\
(1.661)\end{array}$ & $\begin{array}{c}-23.23^{* * *} \\
(0.276)\end{array}$ & $\begin{array}{l}0.306^{* * *} \\
(0.0104)\end{array}$ & $\begin{array}{c}0.178^{* * *} \\
(0.00156)\end{array}$ \\
\hline \multicolumn{5}{|l|}{ Fixed effects } \\
\hline Firm size & Yes & Yes & Yes & Yes \\
\hline Firm age & Yes & Yes & Yes & Yes \\
\hline Industry $\times$ State FE & Yes & Yes & Yes & Yes \\
\hline Number of obs & 403693 & 403693 & 492477 & 492477 \\
\hline Adjusted Rsquared & 0.0272 & 0.0271 & 0.0632 & 0.0630 \\
\hline
\end{tabular}

Note: Standard errors clustered at the state*industry level. Labour productivity Q1 is the bottom quartile and is the base case. Source: Authors' calculation based on STP and BIT data.

35. As outlined in Section 6, this greater resilience of high productivity firms to the shock raised aggregate labour productivity by an estimated 4.3-5.6 per cent, relative to a counterfactual where the pandemic completely severed the link between reallocation and productivity (i.e. $\beta=0$ in equation 2 ). The corollary is that if this counterfactual was realised - and high and low productivity firms (within industry and firm size and age classes) adjusted identically to the shock - then the pandemic would have wiped-out 34 years' worth of aggregate labour productivity growth via distorted market selection and reallocation. ${ }^{13}$

36. The results also suggest that firm employment adjustments and exit are most responsive to productivity amongst smaller firms (Figure 3 ). By contrast, there is no evidence of a statistically significant relationship between employment growth and productivity over the course of the pandemic amongst the

\footnotetext{
12 Net employment in firms rolling off remained broadly unchanged (Australian Treasury 2021), suggesting this was driven by labour moving between firms, rather than into unemployment.

${ }^{13}$ In the 30 years prior to the pandemic, aggregate labour productivity growth (GDP per worker) averaged around $1.5 \%$ per annum in Australia. Growth has been lower in recent years, suggesting an even bigger impact.
} 
largest firms (i.e. 200+ employees), though this may in part reflect the smaller sample. The same is true with respect to exit and productivity for firms with more than 50 employees. This may reflect the benefits of scale, meaning that large firms could more effectively ride-out the shock, renegotiate loan commitments and access policy support. The connection between reallocation and productivity is also somewhat stronger amongst younger firms, but these differences are often not statistically significant (see Table A.4, Annex A).

\section{Figure 3. Difference in performance between high and low productivity firms: long change}

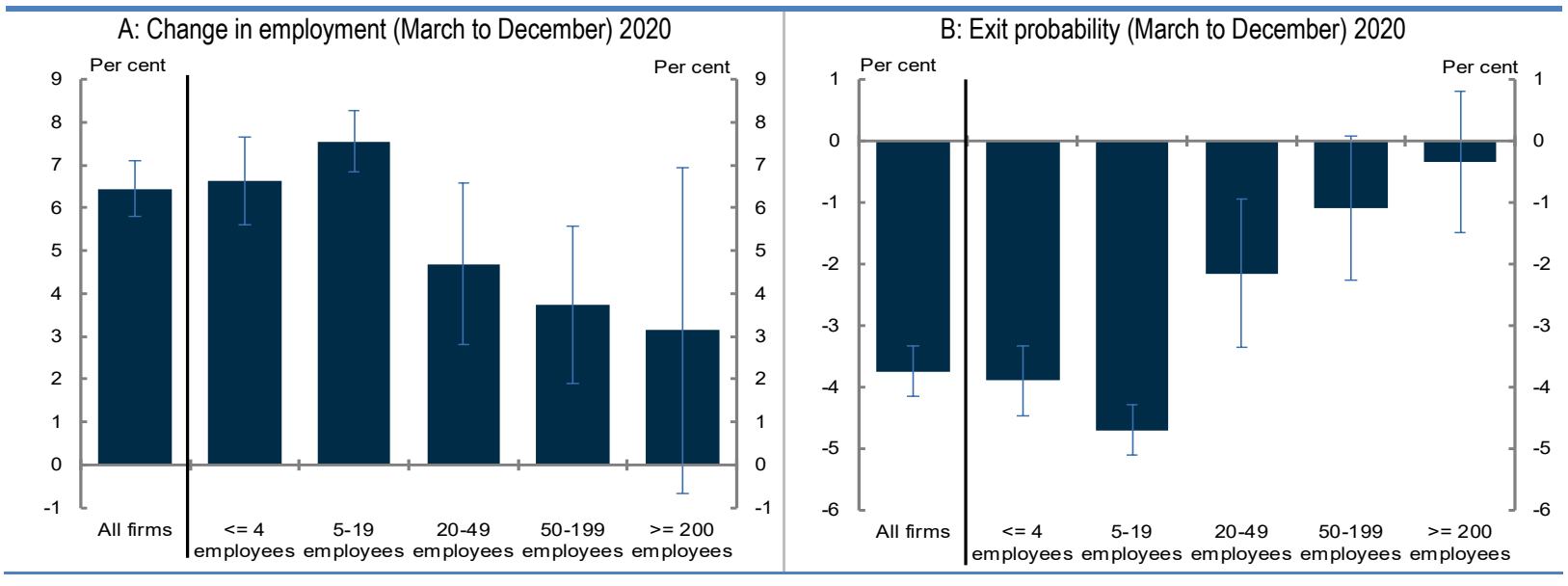

Note: Plots the gap in model-predicted growth between high and low productivity firms, where high and low productivity firm are $+/$ - one standard deviations above the mean, respectively, based on the sub-group under examination (e.g. high and low productivity large, or small, firms). Coefficients taken from baseline regression run on sub-samples, as indicated in chart. Ranges show estimates using the upper and lower bounds of $90 \%$ confidence intervals on the coefficients. Econometric estimates are kept in Annex A Table A.3.

Source: Authors calculation based on STP and BIT data.

37. Between March and May 2020, the reallocation-productivity link is strongest for the Australia economy as a whole (Figure 4, Panel A). Thereafter, it weakens but the resurgence of COVID-19 in Victoria from June underpins a pick-up in this relationship In Victoria (Figure 4, Panel B). In the early months of the pandemic, we also observe a stronger reallocation-productivity link in those hard-hit industries, suggesting that job losses were disproportionately concentrated in lower productivity firms in activities such as Hospitality and Arts \& Recreation (Figure A.3, Annex A). These results suggest that productivity-enhancing reallocation was strongest when economic activity was weakest, consistent with the cleansing hypothesis (Box 2). But these sources of cross-state and industry heterogeneity narrowed significantly over late 2020. 
Figure 4. Difference in performance between high and low productivity firms: monthly change

Change in employment from March 2020 to specified month

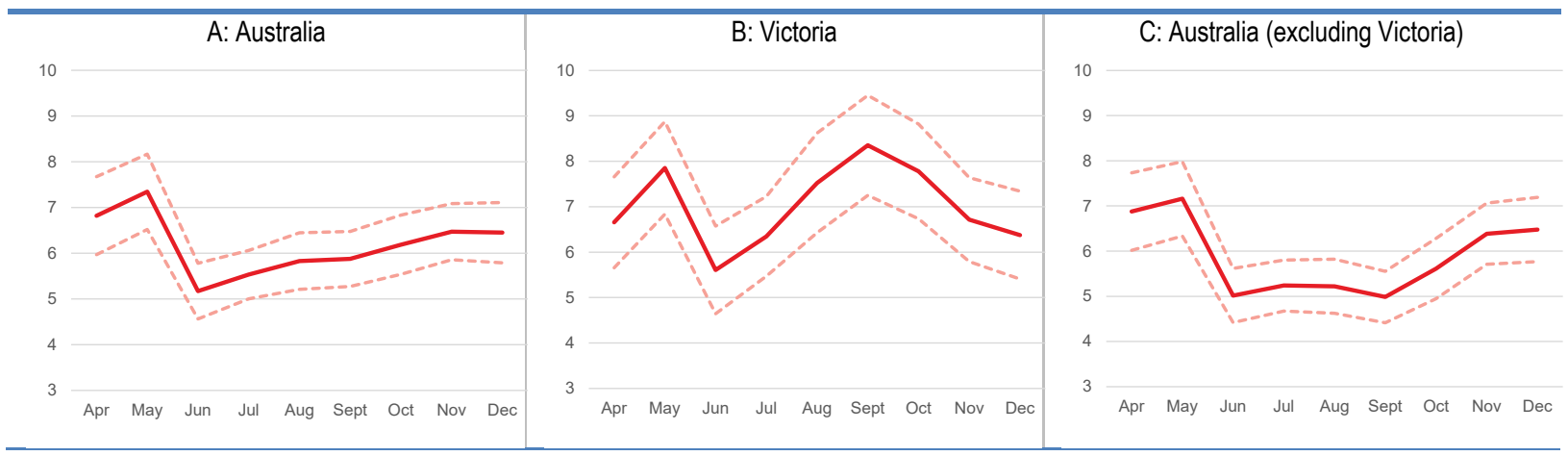

Note: The red line shows the estimated difference in employment growth between a high productivity firm (one with LP 1 standard deviation above the industry mean) and a low productivity firm (one with LP 1 standard deviation below the industry mean). The dashed line denotes the 90 percent confidence intervals.

Source: Authors calculation based on STP and BIT data.

\subsection{Robustness}

38. The baseline results are robust to a range of tests, as outlined in Annex $B$. These include:

i) Using a turnover-based measure of labour productivity, instead of value-added sales, to ensure firms with zero or negative value-added sales are not dropped from the sample. Coefficient estimates are slightly smaller though similar to our baseline model using turnover based labour productivity (Table B.1).

ii) Using an employment growth rate constructed from a headcount of employees with paid employment (Table B.2). We further use this paid employment measure as a robustness check for the model in Section 6.1 (Table B.3).

\section{Productivity, Reallocation and JobKeeper}

\subsection{Empirical framework}

39. While the JobKeeper scheme was associated with a noticeable decline in the overall rate of job reallocation (i.e. "Hibernation"), its impact on the reallocation-productivity is less clear. Accordingly, we explore whether the efficiency of labour reallocation varies according to the usage of JobKeeper at the local labour market level by estimating the following specification:

$$
\Delta E_{i s r}=\alpha+\beta_{1} L P_{i s r}+\beta_{2} L P_{i s r} * J K E s h_{s r}+\delta_{1} L P_{i s r} * C y c l e_{s r}+X_{i s r}+\rho_{s r}+\varepsilon_{i s r}
$$

Where: $E$ is cumulative change in employment between March 2020 and December 2020 (see Equation 1). All explanatory variables are identical to the baseline specification with two key exceptions. First, we include an interaction term between firm level labour productivity term and JKEsh, which measures the 
share of employees in a 4-digit ANZSIC industry in a given state that received the JobKeeeper subsidy. ${ }^{14}$ If $\beta_{2}>0\left(\beta_{2}<0\right)$, then job reallocation was on average more (less) productivity-enhancing - and high productivity firms were more (less) resilient to the shock - in local labour markets with an above-average share of the workforce were covered by JobKeeper. ${ }^{15}$ Second, given that receipt of the subsidy was a function of economic distress, we also include an interaction between LP and the state-industry specific business cycle (Cycle), proxied by the percentage change in employment at the (3-digit ANZSIC) industrylevel within a given state since February 2020 (these data are sourced from the Australian Bureau of Statistics Detailed Labour Force Survey). Standard errors are clustered at the state-industry level.

40. While equation 3a estimates how JobKeeper shaped the reallocation-productivity link on average over the life of the scheme, the effect of the policy may have changed over time, particularly given the strong recovery observed in Australia. To consider this, we exploit the fact that the scheme had multiple stages, and that firms had to re-qualify between the stages. In particular, from 1 April to 27 September, firms could qualify for the scheme if they had a reasonable expectation that their turnover would decline beyond a given threshold. In July 2020, the Australian Government announced an extension to the scheme until 28 March 2021 but in order to receive the subsidy after late September 2020, firms actual turnover in the September quarter had to decline beyond a given threshold (henceforth JobKeeper 2.0). There were also a number of other design changes to the JobKeeper scheme, which are described in more detail in Box 1.

41. Given the strong economic recovery underway in most sectors of the economy over the second half of 2020 , JobKeeper 2.0 protected a narrower subset of firms. This included firms in sectors that were still heavily affected by economic restrictions. But also potentially firms that had simply been less adaptable to the economic consequences of the shock, along with firms that had been on a downward trajectory even prior to COVID. We can use this change in the conditions and coverage to try to understand how much productivity-enhancing reallocation the policy was holding back before it was wound down.

42. Specifically, we adapt equation [3a] in two ways to explore the implications of the phasing-out of JobKeeper. First, we re-estimate the model where the dependent variable is the change in employment from March to May or August 2020 to estimate the implications of the JobKeeper 1.0 regime for the reallocation-productivity link over time. Second, to explore the implications of transition from JobKeeper 1.0 to JobKeeper 2.0, we estimate the following specification:

$$
\begin{gathered}
\Delta E_{i s r}=\alpha+\gamma_{1} L P_{i s r}+\gamma_{2} L P_{i s r} *\left[J K 1 E s h-J K 2 E s h_{s r}\right]+\delta_{1} L P_{i s r} * \text { Cycle }_{s r}+X_{i s r}+\rho_{s r} \\
+\varepsilon_{i s r}
\end{gathered}
$$

Where: $E$ is cumulative change in employment between September 2020 and November 2020 (see equation 1). The specification also includes an interaction term between firm-level labour productivity term and JK1Esh - JK2Esh, which captures the change in the share of subsidised employment in a local labour market between JobKeeper 1.0 and JobKeeper 2.0. By construction, JK1Esh - JK2Esh will be more positive in those industry-state cells that had fewer workers covered under JobKeeper 2.0, relative to under JobKeeper 1.0, and thus captures the extent to which the JRS was phased-out and labour was freed for reallocation. If $\mathrm{y}_{2}>0$, then productivity-enhancing reallocation was stronger in those local labour markets that had more of their workforce released from the scheme and thus potentially available to reallocate from less productive to more productive firms. We also estimate an alternate specification where we include JK1Esh and JK2Esh separately, which produces similar results. All other explanatory variables are

\footnotetext{
14 This is the most fine-grained industry definition in the Australian ANZSIC classification, including industries such as Cafes \& Restaurants (4512) and Takeaway Food Services (4512).

${ }^{15}$ We de-mean the JKEsh term, so that $\beta_{1}$ in Equation [3a] can be interpreted as the extent of productivity-enhancing reallocation for a local labour market with the (sample) average coverage of JobKeeper. We follow this de-meaning procedure for all subsequent interaction variables in the paper.
} 
identical to above, though we allow the cycle variable to account for different overall market outcomes across the March to August, and August to November periods.

\subsection{Productivity, reallocation and JobKeeper}

43. Column 1 of Table 2 shows the estimation results of equation [3a], where the dependent variable is the cumulative change in employment from March to November 2020. The coefficient on productivity is again positive and significant, suggesting that in local labour markets with the (sample) average JobKeeper employment share, (within-industry) labour reallocation remained productivity-enhancing. The Productivity $x J K$ Esh interaction term is positive and statistically significant, even after controlling for the magnitude of the economic shock on the reallocation-productivity link at the state-industry level. This suggests that on average over the life of the JobKeeper scheme, those local labour markets that had a higher proportion of workforce in receipt of JK perversely exhibited a stronger (within-industry) connection between labour reallocation and productivity. This provides further evidence in support of the notion of "hibernation, not zombification." However, it is possible that the effects of the policy changed over time.

44. Columns 2 and 3 explore the reallocation-productivity link under the JobKeeper 1.0 regime, where the dependent variable is the change in employment from March to August (column 2) and May (column 3). In both cases, the coefficient on the Productivity $x$ JK-1 Esh interaction term is positive and statistically significant but is somewhat larger than in Column 1. This suggests that JobKeeper may have become more distortive over time.

45. This result is supported by the results looking at the phase down from the JobKeeper 1.0 to JobKeeper 2.0 regime. Column 4 of Table 2 shows the estimation results of equation [3b], where the dependent variable is the cumulative change in employment from September to November 2020. The Productivity $\times$ (JK-1 Esh less JK-2 Esh) interaction term is positive and statistically significant. This suggests that (within-industry) productivity-enhancing labour reallocation was stronger in those local labour markets that had more of their workforce released from JobKeeper and thus potentially available to reallocate from low to high productivity firms. Thus, it appears that the policy was becoming distortionary as the economy recovered - preventing labour from flowing to more productive firms - and that this distortion was partly removed with the phasing-down of the program.

46. This result is confirmed by negative and statistically significant Productivity $x$ JK-2 Esh interaction term in an alternate specification in Column 5. For a given share of local employment covered by JobKeeper 1.0, (within-industry) productivity-enhancing labour reallocation was thus stronger in those local labour markets with a smaller share of the workforce locked-up in JobKeeper 2.0. 
Table 2. Firm-level growth responsiveness to productivity: role of JobKeeper

\begin{tabular}{|c|c|c|c|c|c|}
\hline & \multicolumn{5}{|c|}{ Cumulative change in firm-level employment } \\
\hline & \multicolumn{3}{|c|}{ From Mar-20 until: } & \multirow{2}{*}{\multicolumn{2}{|c|}{$\begin{array}{l}\text { From Sept-20 until } \\
\text { Nov-20 }\end{array}$}} \\
\hline End date: & Nov-20 & Aug-20 & May-20 & & \\
\hline & (1) & (2) & (3) & $(4)$ & (5) \\
\hline \multicolumn{6}{|l|}{ Productivity and JobKeeper } \\
\hline Labour productivity $_{\text {isr }}$ & $\begin{array}{c}2.592^{* * *} \\
(0.131)\end{array}$ & $\begin{array}{c}2.259^{* * *} \\
(0.121)\end{array}$ & $\begin{array}{c}2.936^{* * *} \\
(0.123)\end{array}$ & $\begin{array}{c}0.757^{\star * *} \\
(0.121)\end{array}$ & $\begin{array}{c}0.756^{* * *} \\
(0.121)\end{array}$ \\
\hline Labour productivity $_{\text {isr }} \times \mathrm{JK} \mathrm{Esh}_{\mathrm{sr}}$ & $\begin{array}{l}0.0249^{* \star *} \\
(0.00686)\end{array}$ & & & & \\
\hline Labour productivity $\mathrm{isr}_{\mathrm{sr}} \times \mathrm{JK}-1 \mathrm{Esh}_{\mathrm{sr}}$ & & $\begin{array}{c}0.0277^{* * *} \\
-0.00635\end{array}$ & $\begin{array}{c}0.0391^{* * *} \\
(0.0064)\end{array}$ & & $\begin{array}{c}0.0404^{* * *} \\
-0.0102\end{array}$ \\
\hline Labour productivity $_{\text {isr }} \times\left(\mathrm{JK}-1 \mathrm{Esh}_{\mathrm{sr}}\right.$ less JK-2 Esh $\left.\mathrm{sr}_{\mathrm{sr}}\right)$ & & & & $\begin{array}{c}0.0409^{* * *} \\
(0.0103)\end{array}$ & \\
\hline Labour productivity $_{\text {isr }} \times \mathrm{JK}-2 \mathrm{Esh}_{\mathrm{sr}}$ & & & & & $\begin{array}{c}-0.0466^{* * *} \\
(0.0135)\end{array}$ \\
\hline \multicolumn{6}{|l|}{ Cyclical controls } \\
\hline Labour productivity $_{\text {isr }} \times \Delta \mathrm{Emp}_{\mathrm{sr}}$ (Feb-20 to end date) & $\begin{array}{l}-0.00294 \\
-0.00433\end{array}$ & $\begin{array}{c}-0.0210^{* * *} \\
(0.00476)\end{array}$ & $\begin{array}{l}-0.0139^{* *} \\
(0.00426)\end{array}$ & $\begin{array}{c}0.00392 \\
(0.00210)\end{array}$ & $\begin{array}{c}0.0038 \\
(0.00207)\end{array}$ \\
\hline Labour productivity $_{\text {isr }} \times \Delta \mathrm{Emp}_{\mathrm{sr}}$ (Aug-20 to end date) & & & & $\begin{array}{l}-0.00136 \\
(0.00232)\end{array}$ & $\begin{array}{l}-0.00127 \\
(0.00230)\end{array}$ \\
\hline \multicolumn{6}{|l|}{ Fixed Effects } \\
\hline Industry $\times$ State & Yes & Yes & Yes & Yes & Yes \\
\hline Firm Size Class & Yes & Yes & Yes & Yes & Yes \\
\hline Firm Age Class & Yes & Yes & Yes & Yes & Yes \\
\hline Number of observations & 381721 & 383687 & 386600 & 444931 & 444931 \\
\hline Adjusted R-squared & 0.0255 & 0.0250 & 0.0633 & 0.0278 & 0.0278 \\
\hline
\end{tabular}

Note: Constant not shown. Standard errors clustered at the state*industry level.

Source: Authors calculation based on STP and BIT data.

47. To illustrate the economic magnitude of these effects, Figure 5 simulates the difference in employment growth between a high and low productivity firm for various time periods, according to the share of local employment covered by JobKeeper, and across the two policy regimes. The middle panel shows that in a state-industry pairing where a high share of workforce (i.e. $60 \%$ ) was covered by JobKeeper 1.0, employment growth (over March and August 2020) that was 6.8 percentage points higher in a high (versus low) productivity firm. This compares to an employment growth differential of around 3.6 percentage points in those parts of the economy where JobKeeper had low coverage (i.e. $15 \%$ of employees). This differential is even wider over the initial months of the pandemic (left panel).

48. The final panel of Figure 5 illustrates how differences in the extent to which JobKeeper was phased-out shaped productivity-enhancing reallocation dynamics. In those parts of the economy where a large share of employment (i.e. 38\%) was released from JobKeeper, employment growth in high productivity firms was 3.5 percentage points higher than in low productivity firms, over September and November 2020. This compares to a meagre employment growth differential of just 0.4 percentage points in those state-industry cells where only a small share of employment (i.e. $7 \%$ ) was released from JobKeeper. Put differently, in those parts of the economy where little labour was released by the phase down, the reallocation- productivity link was distorted and there was virtually no productivity-enhancing labour reallocation. 


\section{Figure 5. Productivity-enhancing reallocation varied across labour markets according to JobKeeper coverage}

Employment growth gap between high and low productivity firms, across high and low JobKeeper uptake sectors

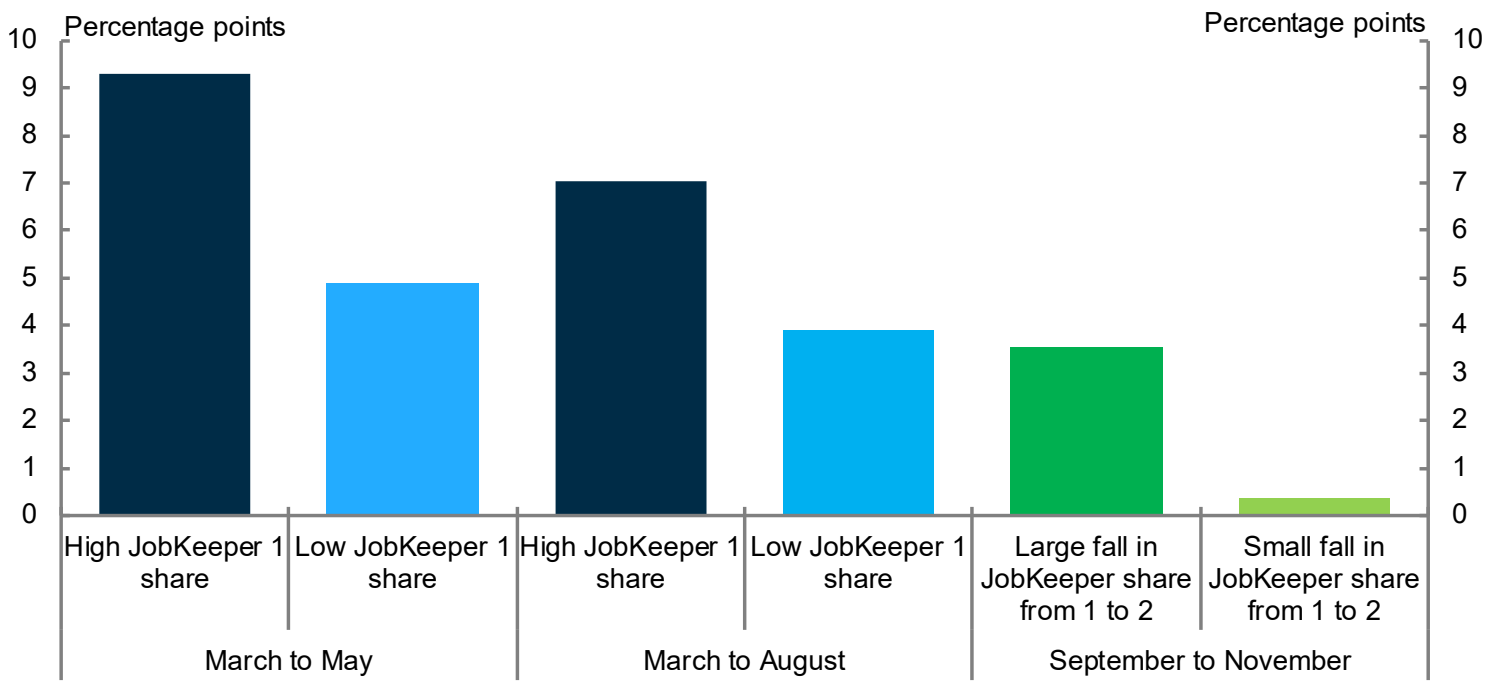

Note: High/low productivity firms are $+/ 1$ standarddeviation from the mean of the productivity distribution. High JobKeeper 1 share is $60 \%$ and low is $15 \%$. Large fall in JobKeeper share is 38 percentage points. Small fall is 7 percentage points. These represent 10 th and 90 th percentiles of industry*state distribution.

Source: Authors calculation based on STP and BIT data.

49. Our results do not imply that the second phase of the JobKeeper Scheme was not warranted. A number of sectors were still heavily affected by pandemic-induced restrictions, particularly in Victoria, and thus some policy support was necessary. The policy also had additional aims, including supporting worker incomes alongside welfare payments, and reducing uncertainty (Australian Treasury 2021). But it highlights the fact that JRS are likely to become more distortive over time, underscoring the need to phased-out such schemes where possible - which is what exactly occurred in the case of JobKeeper.

50. Before proceeding, the cyclical controls warrant discussion. ${ }^{16}$ In columns 2 and 3 of Table 2, the $\mathrm{LP}^{*}$ Cycle interaction terms is negative and statistically significant, suggesting that labour reallocation was more productivity-enhancing in those local labour markets that experience a larger decline in aggregate employment over the first six months of the pandemic (although this is less evident by November once much of the economic recovery had occurred). ${ }^{17}$ This provides more direct evidence for the cleansing hypothesis, confirming the suggestive evidence outlined in Section 4.2.

\section{Which firms took-up the JobKeeper subsidy?}

51. Why was the reallocation-productivity link stronger in those parts of the economy that were initially more shielded by JobKeeper? And why did policy shift from supportive to distortive over time? One possible

16 These cyclical variables are unaffected by the exclusion of the JobKeeper share variable. This indicates that that multi-collinearity is not an issue, and that we have enough variation to separately identify the cyclical and JobKeeper effect. The results below on take-up provide further evidence that what we identify is related to the effects of JobKeeper, rather than cyclical factors. These results are available on request.

17 Note that this is not the case in columns 4 and 5. This is not surprising, given this focuses on outcomes over a much shorter period that is more distant from the peak of the crisis. 
explanation lies in the characteristics of the firms that took-up the JRS, and how this changed between the two phases of the scheme. The zombification hypothesis assumes that less productive firms are more likely to receive government support, which in turn crowds-out growth opportunities for more productive firms. We thus consider productivity differences between subsidised and non-subsidised firms, as well as the relative propensity of productive but financially fragile firms to utilise the scheme.

\subsection{Empirical framework}

52. To explore these mechanisms, we estimate linear probability models of the form:

$$
J K_{i s r}^{\text {regime }}=\alpha+\varphi_{1} L P_{i s r}+\varphi_{2} L P_{i s r} * \text { FinCons }_{i s r}+\varphi_{3} * \text { FinCons }_{i s r}+X_{i s r}+\rho_{s r}+\varepsilon_{i s r}
$$

Where: $\mathrm{JK}$ is a dummy variable that equals one if a firm is a recipient of the JobKeeper subsidy, zero otherwise, with separate models run for each regime (i.e. JobKeeper 1.0 and JobKeeper 2.0; regime=2). LP is firm-level labour productivity, which is included separately and interacted with various indicators of financial constraints that would leave a firm particularly exposed to the shock (FinCons). ${ }^{18}$ First, we include a dummy variable that equals one if a firm has insufficient liquid assets (i.e. cash reserves) to cover six months' worth of expenses (based on 2018/19 BIT data), zero otherwise (Liquid). Second, we include a variable that captures the share of the firm's expenses that are 'fixed' (rent, leases and interest costs based on 2018/19 BIT data) (FixCost). The latter term is included since fixed costs are still incurred during pandemic-induced disruptions to commercial activity and thus firms with a high share of fixed costs may be more likely to apply for JobKeeper. $X$ includes dummies for firm size and age classes, as defined above, and the wage share of total expenses. Finally, the model includes interacted industry and state fixed effects, such that we are identifying how participation in JobKeeper is related to differences in firm productivity within narrowly defined sectors, after controlling for state-level shocks.

53. The coefficients of interest are $\varphi_{1}$ and $\varphi_{2}$. If $\varphi_{1}>0$ and $\varphi_{2}>0$, then the JobKeeper subsidy was taken up by more productive firms on average, and particularly financially constrained productive firms, suggesting that JobKeeper work as an effective crisis tool to shield the productive fabric of the economy. By contrast, if $\varphi_{1}<0$, then less productive firms were more likely to take-up the subsidy, lending more credence to the Zombification hypothesis. Changes in these coefficients over time will also provide further insights into changes in the effects of the policy over time.

\subsection{Empirical results}

54. Table 3 shows the estimation results of equation [4]. Separate linear probability models are estimated for the two policy regimes, with estimates for JobKeeper 1.0 and JobKeeper 2.0 shown in Panel $A$ and Panel B respectively. Overall, high productivity firms were significantly more likely than low productivity firms to take-up the subsidy under JobKeeper 1.0, but this was not the case under JobKeeper 2.0.

55. Focusing on Panel A, the coefficient on labour productivity in Column 1 is positive and statistically significant at the $1 \%$ level. This suggest that within industries, more productive firms were more likely to participate in JobKeeper 1.0, after accounting for a firm's size, age and state. This result remains after controlling for the state of firm's pre-pandemic balance sheet (Column 2), which reveals a higher probability of JobKeeper take-up amongst firms that were illiquid or had a high share of fixed costs in expenses. The latter is unsurprising given that the pandemic - and measures to curb the spread of the virus - shutdown commerce in some instances, which would have been more harmful for firms with limited cash reserves

\footnotetext{
${ }^{18}$ For some discussion of the roles of liquidity constraints during COVID, see for example OECD (2020).
} 
and that still had significant (fixed) costs to cover, despite ramping down production. Column 3 shows that firms in the second, third and highest (within-industry) productivity quartiles were more likely to participate in Job Keeper 1.0, than firms in the least productive quartile.

\section{Table 3. The JobKeeper Scheme, firm-level productivity and financial constraints}

Dependent variable: probability that a firm participates in JobKeeper

\begin{tabular}{|c|c|c|c|c|c|c|c|c|}
\hline & \multicolumn{4}{|c|}{ JobKeeper 1.0} & \multicolumn{4}{|c|}{ JobKeeper 2.0} \\
\hline & (1) & (2) & (3) & (4) & (5) & (6) & (7) & (8) \\
\hline \multicolumn{9}{|l|}{ Productivity } \\
\hline Labour productivity ${ }_{\text {isr }}$ & $\begin{array}{l}0.0246^{* * *} \\
(0.0006)\end{array}$ & $\begin{array}{c}0.0296^{* * *} \\
(0.0010)\end{array}$ & & $\begin{array}{c}0.0257^{* \star *} \\
(0.0019)\end{array}$ & $\begin{array}{c}-0.0050^{* * *} \\
(0.0005)\end{array}$ & $\begin{array}{c}-0.0023^{* * *} \\
(0.0009)\end{array}$ & & $\begin{array}{c}0.0009 \\
(0.0017)\end{array}$ \\
\hline Labour productivityQ2 $2_{\text {isr }}$ & & & $\begin{array}{c}0.0953^{* \star *} \\
(0.0028)\end{array}$ & & & & $\begin{array}{c}0.0229^{* * *} \\
(0.0025)\end{array}$ & \\
\hline Labour productivityQ $3_{\text {isr }}$ & & & $\begin{array}{l}0.100^{* * *} \\
(0.0028)\end{array}$ & & & & $\begin{array}{c}0.0075^{* \star *} \\
(0.0024)\end{array}$ & \\
\hline Labour productivityQ $4_{\text {isr }}$ & & & $\begin{array}{c}0.0716^{* \star *} \\
(0.0028)\end{array}$ & & & & $\begin{array}{c}-0.0122^{* * *} \\
(0.0025)\end{array}$ & \\
\hline Labour productivity $_{\text {isr }} \times$ Liquid $_{\text {isr }}$ & & & & $\begin{array}{l}0.0047^{* *} \\
(0.0021)\end{array}$ & & & & $\begin{array}{l}-0.0012 \\
(0.0019)\end{array}$ \\
\hline Labour productivity $_{\text {isr }} \times$ FixCost $_{\text {isr }}$ & & & & $\begin{array}{c}0.0078 \\
(0.0080)\end{array}$ & & & & $\begin{array}{c}-0.0391^{\star \star \star} \\
(0.0071)\end{array}$ \\
\hline \multicolumn{9}{|l|}{ Balance sheet } \\
\hline Liquid $_{\text {isr }}$ & & $\begin{array}{c}0.0532^{* \star *} \\
(0.0024)\end{array}$ & $\begin{array}{c}0.0461^{* * *} \\
(0.0023)\end{array}$ & $\begin{array}{c}0.0017 \\
(0.0229)\end{array}$ & & $\begin{array}{c}0.0175^{\star \star *} \\
(0.0021)\end{array}$ & $\begin{array}{c}0.0142^{* * *} \\
(0.0021)\end{array}$ & $\begin{array}{c}0.0302 \\
(0.0204)\end{array}$ \\
\hline FixCost $_{\text {isr }}$ & & $\begin{array}{l}0.279^{\star \star \star} \\
(0.0124)\end{array}$ & $\begin{array}{l}0.248^{\star * \star} \\
(0.0121)\end{array}$ & $\begin{array}{l}0.198^{* *} \\
(0.0855)\end{array}$ & & $\begin{array}{l}0.244^{* \star *} \\
(0.0110)\end{array}$ & $\begin{array}{l}0.222^{* * *} \\
(0.0107)\end{array}$ & $\begin{array}{l}0.656^{\star \star \star} \\
(0.0758)\end{array}$ \\
\hline \multicolumn{9}{|l|}{ Controls and Fixed Effects } \\
\hline Wage share of expenses $s_{\text {isr }}$ & No & Yes & Yes & Yes & No & Yes & Yes & Yes \\
\hline Firm Size Class & Yes & Yes & Yes & Yes & Yes & Yes & Yes & Yes \\
\hline Firm Age Class & Yes & Yes & Yes & Yes & Yes & Yes & Yes & Yes \\
\hline Industry & Yes & Yes & Yes & Yes & Yes & Yes & Yes & Yes \\
\hline State & Yes & Yes & Yes & Yes & Yes & Yes & Yes & Yes \\
\hline Number of observations & 288,684 & 288,684 & 292,223 & 288684 & 285,385 & 285,385 & 288,887 & 285,385 \\
\hline Adjusted R-squared & 0.097 & 0.102 & 0.0104 & 0.102 & 0.079 & 0.081 & 0.104 & 0.081 \\
\hline
\end{tabular}

Note: constant not shown. Standard errors clustered at the state*industry level.

Source: Authors' calculation based on BIT data.

56. These results are consistent with canonical models of firm dynamics (Hopenhayn, 1992; Jovanovic, 1982). When faced by uncertain future outcomes - and some fixed costs of operation - high productivity firms are likely to take on the cost and operate, given the higher expected value of doing so. So when all firms were faced with a broad-based and uncertain COVID-shock, more productive firms would have had more incentive to take-up the subsidy, given they see greater firm value in the medium-term.

57. One potential concern regarding the results might be that positive correlation between JobKeeper take-up and firm-level productivity reflects the fact that short-tenure casual workers - i.e. those with less than 12 months of tenure - were ineligible for the JobKeeper subsidy. Moreover, modelled productivity will be lower for such firms, as they will have a higher modelled headcount, and thus lower labour productivity all else equal. To address this concern, we re-run the take-up model using measures of profitability - such as Return on Assets and a loss-maker dummy - that are not subject to the same measurement concern. When we do so, we find that firms taking up JobKeeper 1.0 were more profitable, but those taking up JobKeeper 2.0 were not (Annex B Table B.3), consistent with the baseline productivity results.

58. While more productive firms were more likely to participate in JobKeeper 1.0, the positive and significant Productivity X Liquid interaction term in Column 4 on Panel A suggests that this was particularly the case for those productive firms that were financially constrained. Figure 6 Panel A shows the difference 
in probability of take-up of the JobKeeper scheme between a high and low productivity firm, depending on their (pre-crisis) financial vulnerability. While a high productivity firm but financially sound firm was 6.4 percentage points more likely than a low productivity firm to participate in JobKeeper 1.0, this take-up differential rises to 7.6 percentage points amongst financially constrained firms. Given that the premature shakeout of productive but financially fragile firms is mechanism through which recessions can impart scarring effects (Box 2), this suggests that JobKeeper 1.0 worked as an effective crisis tool to shield the productive fabric of the economy.

\section{Figure 6. JobKeeper take-up, firm productivity and vulnerability to the shock}

Difference in probability of take-up of JobKeeper between high and low productivity firms

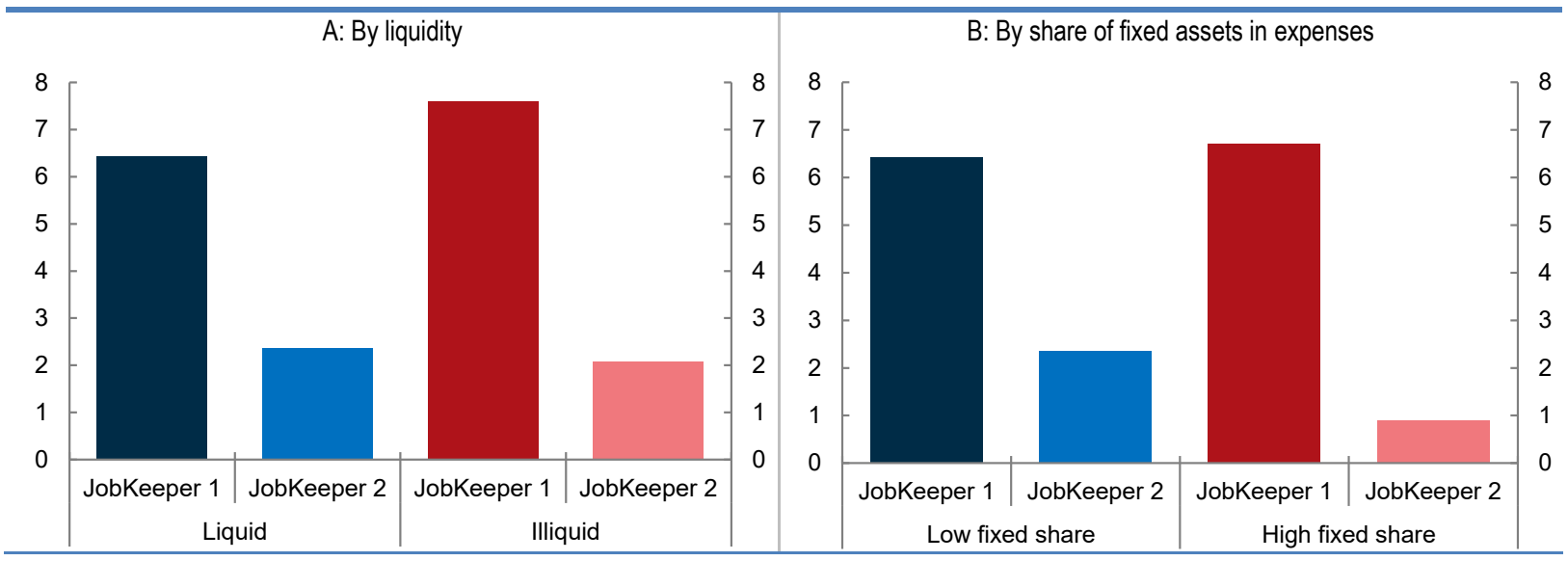

Note: High/low productivity firms are $+/-1$ standard deviation above/below the mean of the productivity distribution.

Source: Authors calculation based on STP and BIT data.

59. Panel B of Table 3 shows that the characteristics of firms receiving JobKeeper 2.0 change in two key respects. First, the estimated coefficient on productivity is now negative and statistically significant (Columns 5 and 6 ). While this suggest that within industries, less productive firms were more likely to participate in JobKeeper 2.0 - controlling for firm size and age, state and (pre-crisis) balance sheet characteristics - the economic magnitude of the coefficient is very small. ${ }^{19}$ This is consistent with leftward shift in the productivity distribution of firms receiving JobKeeper 2.0, relative to JobKeeper 1.0 (Figure 7). Indeed, Column 7 of Table 4 shows that while firms in the second and third (within-industry) productivity quartile were more likely to participate in Job Keeper 2.0 than firms in the least productive quartile, the economic magnitude of these differences are now small. In fact, firms in the most productive quartile were less likely to participate in JobKeeper 2.0, than firms in the lowest productivity quartile.

60. Second, the Productivity $X$ Liquid interaction term in Column 8 is no longer positive but instead statistically insignificant from zero. This suggests that while financially constrained firms remain more likely to participate in JobKeeper 2.0, the scheme no longer disproportionately shields the more productive segment of the financially constrained group of firms. This is reflected in simulations in Figure 6 Panel A, which show very little difference in take-up of JobKeeper 2.0 for high and low productivity firms based on their (pre-crisis) financial capacity. Moreover, the Productivity $x$ Fixed Cost interaction term is now negative and statistically significant. This suggests while firms with a high share of fixed costs in expenses were

\footnotetext{
19 If we exclude the balance sheet controls, we can include a broader sample that include sole-trader unincorporated businesses, who do not report on their balance sheets. Doing so does not affect the JobKeeper 1.0 results. For JobKeeper 2.0, the coefficient on productivity turns from statistically negative, to statistically, or economically, indistinguishable from zero, depending on the specification. So, in this case, firms receiving JobKeeper 2.0 are no longer less productive, though they are not more productive. These results are available on request.
} 
also more likely to take-up JobKeeper 2.0, the scheme tended to disproportionately shield the less productive members of this group.

\section{Figure 7. JobKeeper shielded more productive firms but less so over time}

Distribution of labour productivity for recipient firms under JobKeeper 1 and JobKeeper 2

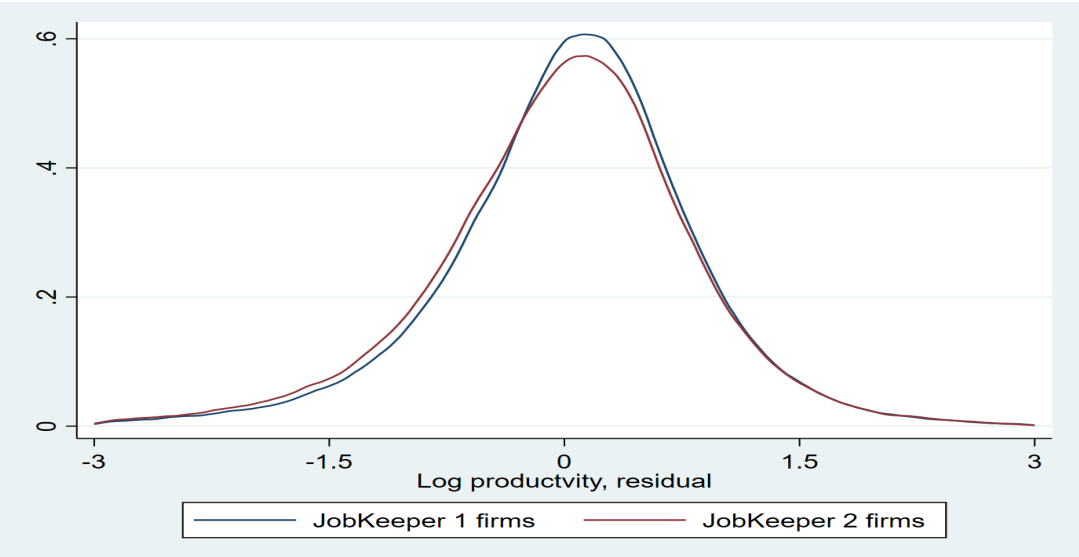

Note: Plots residuals from a regression of labour productivity on balance sheet controls from the above take-up regressions, and age, size, industry and state dummies. Residuals plotted separately for firms in JobKeeper 1.0, and 2.0

Source: Authors calculation based on BIT data.

61. This finding for JobKeeper 2.0 is consistent with the above reallocation results, and with expectations, given the duration of the shock and economic recovery. By this stage, there were two broad groups of firms who were likely to qualify: $i$ ) those in sectors still heavily affected by restrictions; and ii) those firms who were either already on a downward trajectory - and so qualified for year-on-year turnover declines - or who had not adapted. The latter set of firms could generally expected to be less productive, who: i) might have otherwise exited via market selection; or ii) had lower managerial and technological capability, which would have comprised their adaptability in light of the nature of the shock - i.e. one where being online and able to operate remotely were key (Andrews, Charlton and Moore, 2021).

62. It also shows that many - particularly productive - firms no longer needed the payment given the recovery. Without the phase down of the scheme, these firms' hiring decisions would have continued to be distorted by JobKeeper. This highlights the idea that the allocative costs of crisis policies that prioritise preservation - over reallocation - build over time, and justifies the gradual winding down of the JobKeeper scheme.

\section{Aggregate implications}

63. How important was it for aggregate labour productivity that job reallocation and firm productivity remained connected over the course of the pandemic? To address this question, we follow Decker et al (2020) and exploit the following identity to create indexes of aggregate labour productivity $(P)$ :

$$
P_{t}=\sum s_{i t} p_{i t}
$$

Where: $s$ and $p$ are the employment share and $(\log )$ labour productivity level of each firm $i$. We combine actual realisations of firm-level labour productivity (in 2018/19) with the implied predicted employment shares - from the estimated models - over 2020 for three counterfactual policy scenarios: 
1. First, we estimate how much higher aggregate labour productivity was due to the connection between employment growth and (lagged) firm-level productivity demonstrated in Table 1 (Column 1), compared to a counterfactual scenario where the pandemic completely severed the link between reallocation and productivity (i.e. $\beta=0$ in equation 2 ). Under this counterfactual, each firm - within industry, state, firm size and age classes - has the same employment share $(s)$, regardless of their productivity level $(p)$.

2. Second, we estimate the increase in productivity stemming from the boost to the reallocationproductivity nexus associated with JobKeeper. Mechanically this involves using the coefficients in Column 2 of Table 2 to compare the outcomes with the actual reach of JobKeeper 1.0 (JKEShare=actual), relative to a scenario where JobKeeper was never introduced. (JKEShare $=0$ ). This can also be thought of as considering a counterfactual where JobKeeper uptake was not correlated with firm productivity, and so provided no boost to the reallocation-productivity nexus $\left(\beta_{2}=0\right.$ in equation $\left.3 a\right)$.

3. Third, we estimate how much lower aggregate labour productivity would have been if the share of workers covered by JobKeeper 2.0 in each state-industry cell was identical to JobKeeper 1.0 (JK1ESh minus JK2ESh=0), based on the coefficients in Column 4-5 of Table 2. This is akin to a scenario were JobKeeper was not phased out from late September 2020.

64. In each case, the employment share (e) prediction for a firm in $t+1$ applies the model's prediction of employment growth in $t+1$ to the (initial) level of employment for the firm in $t$. We then construct two indexes of aggregate productivity $(P)$ - the actual and counterfactual - for each scenario outlined above and their difference yields the aggregate impact:

$$
P_{t+1}^{\text {Gain }}=\sum_{i}\left(s_{i, t+1}^{\text {Actual }}-s_{i, t+1}^{\text {Counterfactual }}\right) P_{i t}
$$

65. Figure 8 illustrates the results for each scenario. First, the greater resilience of high productivity firms to the pandemic raised aggregate labour productivity by an estimated $51 / 2$ per cent using the baseline model, relative to a counterfactual where the pandemic completely severed the reallocation-productivity link (i.e. 1: Distorted reallocation). The estimate is slightly smaller at $4 \frac{1}{4}$ per cent if we use the JobKeeper 1.0 model to run the same counterfactual (i.e. 1a: Distorted reallocation - JobKeeper specification). In this case, the estimate is more directly comparable to the JobKeeper 1.0 result below, as it uses the same model specification and period, and so better allows us to consider the 'share' of the boost related to JobKeeper.

66. Second, the introduction of the JobKeeper scheme - and more specifically the tendency for JobKeeper 1.0 to disproportionately shield higher productivity firms, thus strengthening the reallocationlink - boosted aggregate labour productivity by an estimated $23 / 4$ per cent. This represent a bit over half of the estimated boost to labour productivity stemming from the reallocation-productivity link. The corollary is that without the JobKeeper Scheme, there would have been more of an indiscriminate shakeout (via contraction or exit) of high productivity - and especially productive but liquidity constrained - firms, imparting significant scarring effects on the economy's productive fabric.

67. Finally, if policymakers did not adjust the JobKeeper scheme from late September 2020, aggregate labour productivity would have been an estimated 2 per cent lower in November, reflecting the increasing allocative distortions of JobKeeper over time. This implies significant aggregate gains from the phase-out of the scheme, although these gains may be temporary in the sense that some adjustment would have invariably occurred when the policy was removed. 


\section{Figure 8. Aggregate implications}

Gain to aggregate labour productivity (\%) in 2020 from actual outcome relative to three counterfactual scenarios

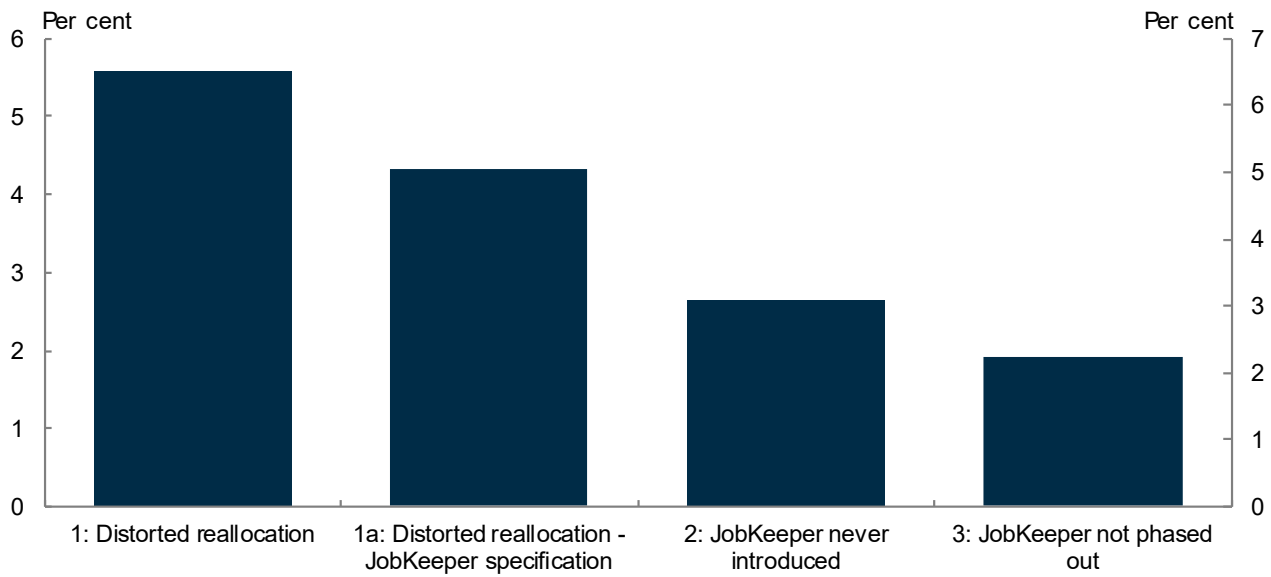

Note: Difference in aggregate productivity using predicted employment outcomes using results reported to this point, and counterfactual scenarios discussed above. Bar 1 is based on the baseline model results in Table 1 column (1), estimated to December. Bar 1a is based on the model results in Table 2 column (1), estimated to August. As such, it is more comparable to the results in Bar 2, which uses the same model. Bar 3 uses the model in Table 2 column (4) estimated from August to November.

Source: Authors calculation based on STP and BIT data.

\section{Conclusion}

68. This paper finds that job reallocation fell following the onset of the pandemic, a non-trivial share of firms were still adding and shedding workers. Moreover, this reallocation process remained linked to productivity: high productivity firms were more likely to expand and low productivity firms remained more likely to contract or exit. That high productivity firms were more resilient to shock helped to minimise the potential scarring effects that an indiscriminate shakeout of productive firms - and the associated destruction of firm-specific intangible capital - would otherwise entail. This suggests that the pandemic may carry relatively benign consequences for medium-term productivity growth in Australia via the reallocation channel. Yet the pandemic may also shape productivity via other channels - such as technology adoption, international knowledge spillovers and human capital accumulation - that will only become clear over time.

69. While our paper represents the first evidence of the impact of the pandemic on reallocationproductivity link using comprehensive administrative data, we also contribute to the ongoing policy debate of the costs and benefits of job retention (or wage subsidy) schemes. Under the first phase of the JobKeeper scheme - which provided broad-based crisis support from April to September 2020 - we show high productivity firms were more likely to take-up JobKeeper. Moreover, the scheme disproportionately shielded productive but financially fragile firms - a pivotal group who's premature exit (or downsizing) is a key mechanism through which recessions can impart scarring effects. One consequence was that productivity-enhancing reallocation was actually stronger in those local labour markets that had a higher proportion of workforce in receipt of JobKeeper. But the scheme appears to have become more distortive over time, impinging on the reallocation-productivity link by preventing reallocation of resources from less to more productive firms.

70. Policies aimed at preserving links between workers and firms during the crisis phase can potentially protect workers from scarring without significantly distorting the firm dynamics of the economy. While this suggests that concerns in some quarters that job retention schemes would lead to zombification were overplayed, our results also demonstrate that there is a fine line between such policies being supportive and distortive. This underscores the need for such crisis policies to be truly temporary and for their design to evolve as economic conditions change. 


\section{References}

Andrews, D., A. Charlton and A. Moore (2021), "COVID-19, Productivity and Reallocation: Real-time evidence from three OECD countries", OECD Economics Department Working Paper No. 1676

Andrews, D., C. Criscuolo and P. Gal (2016), 'The Best versus the Rest: The Global Productivity Slowdown, Divergence across Firms and the Role of Public Policy', OECD Productivity Working Papers, No. 5, OECD Publishing, Paris.

Andrews, D. et al. (2020), "The career effects of labour market conditions at entry", OECD Productivity Working Papers, Vol. 20.

Andrews, D., M. Adalet McGowan and V. Millot (2018), "Confronting the Zombies: Polciies for Productivity Revival”, OECD Economic Policy Papers, Vol. 21, https://doi.org/10.1787/f14fd801-en.

Andrews, D and D. Hansell (2021), Productivity-enhancing labour reallocation in Australia" Economic Record. https://onlinelibrary.wiley.com/doi/full/10.1111/1475-4932.12601

Australian Treasury (2020), The JobKeeper Payment: Three Month Review https://treasury.gov.au/publication/jobkeeper-review

Australian Treasury (2021), 'The labour market during COVID', 2021-22 Budget Paper No. 1 Statement 4 https://budget.gov.au/2021-22/content/bp1/download/bp1_bs4.pdf

Australian Government (2021), Budget 2021-22 https://budget.gov.au/

Bailey, M., C. Hulten and D. Campbell (1992), "Productivity Dynamics in Manufacturing Plants", Brookings Papers on Economic Activity, Vol. 23/Microeconomics, pp. 187-267.

Baldwin, J.R. and W. Gu (2006), Competition, Firm Turnover and Productivity Growth, Research Paper Economic Analysis, Research Paper Series, Statistics Canada

Barlevy, G. (2002), "The Sullying Effect of Recessions", Review of Economic Studies, Vol. 69/1, pp. 6596.

Barrero, J., N. Bloom and S. Davis (2020), "COVID-19 is also a reallocation shock", NBER Working Paper Series.

Barrero, J., N. Bloom and S. Davis (2020), "Why Working From Home Will Stick", University of Chicago, Becker Friedman Institute for Economics Working Paper, Vol. 2020-174.

Bartelsman, EJ. and M. Doms (2000), "Understanding productivity: Lessons from longitudinal microdata" Journal of Economic Literature 38, no. 3:569-95.

Bartik, Alexander W and Bertrand, Marianne and Lin, Feng and Rothstein, Jesse and Unrath, Matt (2020), "Measuring the labor market at the onset of the COVID-19 crisis," NBER Working Paper 27613.

Bishop, J and I. Day (2020), "How Many Jobs Did JobKeeper Keep?" Reserve Bank of Australia Research Discussion Paper 2020-07.

Bloom, N. et al. (2020), "The Impact of Covid-19 on Productivity", NBER Working Paper, 28233, http://dx.doi.org/10.3386/w28233. 
Bloom, N., S. Davis and Y. Zhestkova (2020), "COVID-19 Shifted Patent Applications Toward Technologies that Support Working from Home", University of Chicago, Becker Friedman Institute for Economics Working Pape, Vol. 2020-1.

Bloom, N and J Van Reenen (2007), "Measuring and explaining management practices across firms and countries", The Quarterly Journal of Economics 122(4): 1351-1408.

Buera, F. and B. Moll (2015), "Aggregate Implications of a Credit Crunch: The Importance of Heterogeneity", American Economic Journal: Macroeconomics, Vol. 7/3, pp. 1-42, http://dx.doi.org/10.1257/mac.20130212.

Caballero, R. and M. Hammour (1994), "The cleansing effect of recessions", American Economic Review, Vol. 84/5, pp. 1350-1368.

Caldera Sánchez, A. et al. (2017), "Strengthening economic resilience: Insights from the post-1970 record of severe recessions and financial crises", OECD Economic Policy Papers, No. 20, OECD Publishing, Paris, https://dx.doi.org/10.1787/6b748a4b-en.

Calvino, F., C. Criscuolo and R. Verlhac (2020), Start-ups in the time of COVID-19: Facing the challenges, seizing the opportunities, Voxeu.

Carrington, W. and B. Fallick (2017), "Why Do Earnings Fall with Job Displacement?", Industrial Relations, Vol. 56/4, pp. 688-722, https://doi.org/10.1111/irel.12192.

Crane, LD, R. Decker, A. Flaaen, A. Hamins-Puertolas, and C. Kurz (2020), "Business Exit During the COVID-19 Pandemic: Non-Traditional Measures in Historical Context," FEDS working paper \#2020-089.

Criscuolo, C, P. Gal, C. Menon (2014), 'The Dynamics of Employment Growth: New Evidence from 17 Countries', OECD STI Policy Papers No. 14.

Cros, M, A Epaulard and P Martin (2021), "Will Schumpeter Catch Covid-19?", CEPR Discussion Paper 15834.

Cooper, R, J. Haltiwanger, and J. Willis (2007), "Search frictions: Matching aggregate and establishment observations" Journal of Monetary Economics 54, suppl.: 56-78.

Davis, S, J. Faberman, and J. Haltiwanger (2006), "The flow approach to labor markets: New data sources and micro-macro links" Journal of Economic Perspectives 20, no. 3:3-26.

Davis, S, J. Faberman and J. Haltiwanger (2012), "Labor market flows in the cross section and over time" Journal of Monetary Economics 59, no. 1:1-18.

Davis, S and J. Haltiwanger (1990), "Gross job creation and destruction: Microeconomic evidence and macroeconomic implications," In NBER macroeconomics annual 1990, vol. 5, ed. Olivier Jean Blanchard and Stanley Fischer, 123-86. Cambridge, MA: MIT Press.

Davis, S and J. Haltiwanger (1992), "Gross job creation, gross job destruction, and employment reallocation" Quarterly Journal of Economics 107, no. 3:819-63.

Davis, S and J. Haltiwanger (1999), "On the driving forces behind cyclical movements in employment and job reallocation" American Economic Review 89, no. 5:1234-58.

Davis, S. and T. von Wachter (2011), "Recessions and the Costs of Job Loss", Brookings Paper on Ecomomic Activity, Vol. 43/2, pp. 1-72.

Davis, S., J Haltiwanger, and S.Schuh (1996), Job creation and destruction Cambridge MA: MIT Press

Decker, R, J Haltiwanger, R Jarmin and J Miranda (2018), 'Changing Business Dynamism and Productivity: Shocks vs. Responsiveness' NBER Working Paper No. 24236.

Decker, R., J. Haltiwanger, RS Jarmin and J Miranda (2020), "Changing business dynamism and productivity: Shocks vs. responsiveness", American Economic Review 110(12):3952-3990.

Disney, R, J. Haskel and Y. Heden (2003), Restructuring and Productivity Growth in UK Manufacturing, Economic Journal 113, 666-694. 
Di Mauro, F and C. Syverson (2020), "The COVID Crisis and Productivity Growth" Voxeu https://voxeu.org/article/covid-crisis-and-productivity-growth.

Duval, R., J. Elmeskov and L. Vogel (2007), Structural Policies and Economic Resilience to Shocks, OECD Economics Department Working Paper, https://doi.org/10.1787/140152385131.

Ericson, R and A Pakes (1995), "Markov-perfect industry dynamics: A framework for empirical work" Review of Economic Studies 62, no. 1:53-82.

Foster, L. J. Haltiwanger, and C.J. Krizan (2001), "Aggregate Productivity Growth: Lessons from Microeconomic Evidence." in Edward Dean, Michael Harper and Charles Hulten eds. New Developments in Productivity Analysis, Chicago: University of Chicago Press.

Foster, L. J. Haltiwanger, and C.J. Krizan (2006), "Market selection, reallocation and restructuring in the U.S. retail trade sector in the 1990s," Review of Economics and Statistics 88, no. 4:748-58.

Foster, L., C. Grim and J. Haltiwanger (2014). "Reallocation in the Great Recession: Cleansing or Not?," NBER Working Paper 20427.

Foster, L., C. Grim and J. Haltiwanger (2016). "Reallocation in the Great Recession: Cleansing or Not?," Journal of Labor Economics, vol 34(S1), pages S293-S331.

Gropp, R. et al. (2020), "The Cleansing Effect of Banking Crises”, CEPR Discussion Paper, Vol. $15025 .$.

Haltiwanger, J, R. Jarmin and J. Miranda (2013), "Who Creates Jobs: Small vs Large vs Young" Review of Economics and Statistics 95(2), pp. 347-61.

Hong, G, S Kikuchi and Y U Saito (2020), "What are the Effects of the COVID-19 Crisis on Firm Exit in Japan", RIETI column.

Jacobson, L., R. LaLonde and D. Sullivan (1993), "Earnings Losses of Displaced Workers", American Economic Review, Vol. 83/4, pp. 685-709.

Jovanovic, B (1982) "Selection and the evolution of industry," Econometrica 50(3):649-70

Hopenhayn, $H$ (1992) "Entry, exit, and firm dynamics in long run equilibrium" Econometrica 60(5):112750.

Hopenhayn, H, and R Rogerson (1993), "Job turnover and policy evaluation: A general equilibrium analysis” Journal of Political Economy 101(5):915-38.

Lamorgese, A, A Linarello, M Patnaik, and F Schivardi (2021), "Management Practices and Resilience to Shocks: Evidence from Covid-19", CEPR Discussion Paper No. 15987.

Mora Sanguinetti, J. and A. Fuentes (2012), "An Analysis of Productivity Performance in Spain Before and During the Crisis: Exploring the Role of Institutions", OECD Economics Department Working Papers, Vol. 973.

OECD (2020), 'Corporate sector vulnerabilities during the Covid-19 outbreak: assessment and policy responses', OECD Policy Responses to Coronavirus (COVID-19) Corporate sector vul... https://www.oecd.org/coronavirus/policy-responses/corporate-sector-vulnerabilities-duringthe-covid-19-outbreak-assessment-and-policy-responses-a6e670ea/

Ollivaud, P. and D. Turner (2014), "The Effect of the Global Financial Crisis on OECD Potential Output", OECD Economics Department Working Papers, Vol. 1166.

Osotimehin, S and F. Pappada (2015), "Credit Frictions and the Cleansing Effect of Recessions" Economic Journal 127(602): 1153-1187.

Ouyang, M. (2009), "The scarring effect of recessions", Journal of Monetary Economics, Vol. 56/2, pp. 184-199.

Schumpeter, Joseph A. (1939) Business cycles: A theoretical, historical and statistical analysis of the capitalist process. 2 vols. New York: McGraw Hill. 
32 | ECO/WKP(2021)28

Sedláček, P. (2020), "Lost generations of firms and aggregate labor market dynamics", Journal of Monetary Economics, Vol. 111, pp. 16-31 https://doi.org/10.1016/j.jmoneco.2019.01.007.

Syverson, C. (2004), 'Substitutability and Product Dispersion,' Review of Economics and Statistics, 86 (2), pp. 534-550.

Syverson, C (2011), 'What Determines Productivity?' Journal of Economic Literature, 49 (2): 326-65.

Syverson, C (2020), How will the COVID pandemic affect productivity growth? American Enterprise Institute. 


\section{Annex A. Additional Results}

\section{Box A.1. The COVID-19 Shock and Potential Output}

Since early 2020 , policymakers have focused on managing the health crisis and containing short-term economic fallout from the COVID-19 shock ( $0 \rightarrow R$ in Figure). Yet, as vaccines are rolled out, the extent and speed of the recovery (over $R \rightarrow n$ ) will depend on the ability of policy to minimize any scarring to the key channels of potential output - labour, capital and total factor productivity (TFP).

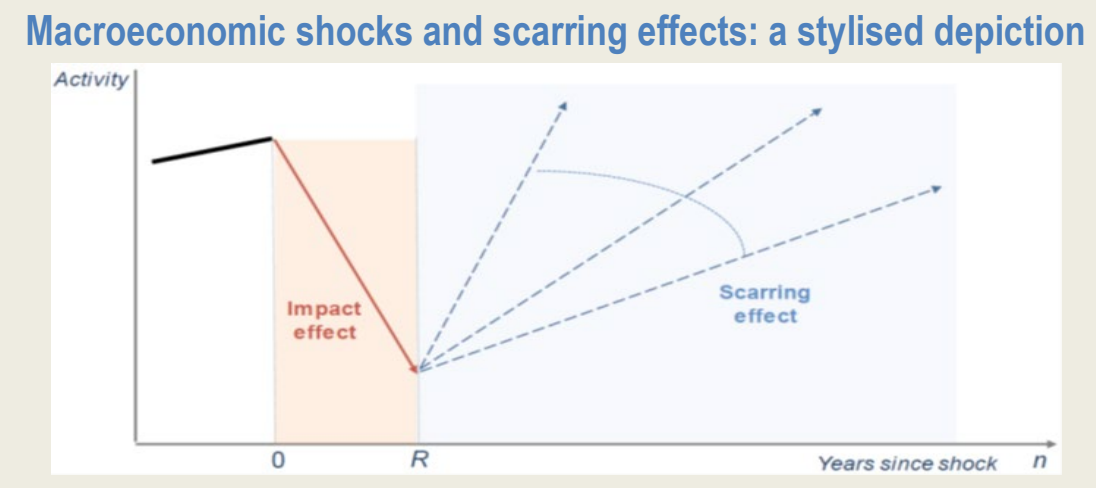

Recessionary episodes over the past 40 years have left lasting scars on the economic fabric of OECD countries, although the key channels can vary over time (Ollivaud and Turner, 2014). The Global Financial Crisis (GFC) adversely affected potential output via the capital deepening and TFP channels. In contrast, the decline in labour force participation was lower than implied by previous severe downturns reflecting the tightening-up of early retirement pathways and other reforms that increased work incentives at older ages.

Di Mauro and Syverson (2020) explore the potential consequences of COVID-19 in the context of a growth accounting framework. With respect to factor quantity and quality, they conjecture that the pandemic may:

- Have minor effects on the size of the potential labour force (i.e. labour input quantity) given that serious (near term) health consequences of the virus have disproportionality fallen on the elderly.

- Reduce labour quality if it disrupts human capital accumulation and workers' skills atrophy due to job separations, or the recessions impairs match quality for recent labour market entrants.

- Weigh on potential capital via higher uncertainty and obsolescence or rapid depreciation of certain types of capital (e.g. hospitality industry premises) if hard-hit sectors do not recover. Against this, the pandemic could result in higher ICT investment and infrastructure spending.

Regarding COVID-19's impact on TFP, they note that policy actions to contain the virus's spread have exacerbated (already rising) cross-border transaction costs and reduced scope for global knowledge spillovers. More specifically, they identify three key margins:

- The within-firm component depends on the way incumbent firms utilise the resources at their disposal. The pandemic could be positive for within-firm productivity if it forces firms to experiment with new organisational modes and adopt leading digital technologies. But many intangible assets - e.g. buyersupplier trust, organisational effectiveness and employee-firm relations - are the product of sunk investments and are non-transferrable, and are lost if a firm exits.

- The between-firm component reflects the potential gains (losses) to aggregate productivity from the pandemic's impact on resource shifts (and firm survival) across the firm productivity distribution within the same sector.

- The between-sector component relates to the pandemic's impact of the resource allocation across sectors. If employment losses are concentrated in sectors with low productivity, this term will be positive. 


\section{Box A.2. Productivity-enhancing reallocation}

There is much potential for the reallocation of scarce resources from low to high productivity firms to raise aggregate productivity due to the widespread heterogeneity in firm-level productivity. For example, even within narrowly defined industries (that is, ready-mix concrete) in the United States, firms at the 90th percentile of the multi-factor productivity (MFP) distribution are twice as productive as firms at the 10th percentile (Syverson, 2004). The literature initially focused on how such large differences in productivity could be sustained in equilibrium, emphasising imperfect product substitutability that prevent customers from easily shifting purchases between producers, and supply-side factors related to technology shocks, management skill and R\&D (Bartelsman and Doms, 2000). More recent studies, however, have emphasised that a small number of star performers disproportionately drive aggregate growth (Haltiwanger et al, 2013), while recognising that many existing technologies remain unexploited by a large share of firms (Andrews, Criscuolo and Gal, 2016).

While the source of these within-firm differences in productivity is complex, the contribution of within-industry reallocation of scarce resources from low to high productivity firms to aggregate productivity growth is significant. For example, Bailey, Hulten and Campbell (1992) found that over a five-year period about half of a typical US industry's MFP growth was due to the reallocation of factors between plants, rather than withinplant productivity growth. In the United Kingdom, this reallocation process accounts for over 80 per cent of MFP growth in the manufacturing sector (Disney et al, 2003), while decompositions for the Canadian economy as a whole and the United States retail sector yield similar conclusions. By contrast, there is less scope for resources to be re-deployed between sectors, reflecting the idea that factors are inherently more substitutable within industries, as well as the tendency for within-sector differences to dwarf between-sector differences in firm behaviour (Foster, Haltiwanger and Krizan, 2001; Mora Sanguinetti and Fuentes, 2012).

These gains to aggregate growth from reallocation are crucial given that reallocation entails costs, which are politically salient. Indeed, the growth of productive firms is necessarily accommodated by via the downsizing or market exit of other firms, which can result in job destruction that may entail: i) persistent earnings losses (Jacobson et al, 1993), as getting knocked-off a partially climbed job ladder leads to a loss of firm-specific human capital, high quality job matches and back-loaded compensation (Carrington and Fallick, 2014); and ii) negative social outcomes with respect to life expectancy, marital stability, emotional well-being and the education outcomes of displaced workers' children (Davis and von Wachter, 2011). 
Table A.1. Distribution of jobs by division in STP

\begin{tabular}{|c|c|c|}
\hline & $\begin{array}{l}\text { Labour } \\
\text { Account }\end{array}$ & STP Payrolls \\
\hline Agriculture, Forestry and Fishing & 3.3 & 1.3 \\
\hline Mining & 1.3 & 1.7 \\
\hline Manufacturing & 6.4 & 6.7 \\
\hline Electricity, Gas, Water and Waste Services & 0.9 & 1 \\
\hline Construction & 8.2 & 6.5 \\
\hline Wholesale Trade & 4.2 & 4.5 \\
\hline Retail Trade & 9.9 & 10 \\
\hline Accommodation and Food Services & 7.3 & 6.4 \\
\hline Transport, Postal and Warehousing & 4.3 & 3.9 \\
\hline Information Media and Telecommunications & 1.2 & 1.3 \\
\hline Financial and Insurance Services & 3.4 & 4.2 \\
\hline Rental, Hiring and Real Estate Services & 1.9 & 2.1 \\
\hline Professional, Scientific and Technical Services & 8.9 & 8.3 \\
\hline Administrative and Support Services & 6.8 & 6.8 \\
\hline Public Administration and Safety & 5.5 & 6.6 \\
\hline Education and Training & 7.2 & 7.8 \\
\hline Health Care and Social Assistance & 14.4 & 14.7 \\
\hline Arts and Recreation Services & 1.4 & 1.6 \\
\hline Other Services & 3.6 & 3.4 \\
\hline
\end{tabular}

Note: Share of total jobs by division. Labour account for December quarter 2020, seasonally adjusted. STP Payrolls for March 2021.

Source: ABS Labour Account, December 2020; ABS Weekly Payroll Jobs and Wages in Australia, Week ending 8 May 'Distribution of jobholder and employer characteristics.

Table A.2. Summary statistics

\begin{tabular}{lcccc}
\hline \hline & $\begin{array}{c}\text { Employment } \\
\text { growth }\end{array}$ & $\begin{array}{c}\text { Log labour } \\
\text { productivity }\end{array}$ & Firm age & Firm size \\
\cline { 2 - 5 } Mean & -18.6 & 10.4 & 12.8 & 22.0 \\
Median & 0.0 & 10.6 & 10.0 & 6.0 \\
Standard deviation & 70.7 & 1.3 & 10.5 & 359.3 \\
25th percentile & -18.2 & 9.8 & 4.0 & 3.0 \\
75th percentile & 10.5 & 11.2 & 19.0 & 15.0 \\
Minimum & -200.0 & 2.7 & 0.0 & 1.0 \\
Maximum & 198.0 & 21.4 & 202.0 & 148667.0 \\
\hline \hline
\end{tabular}

Note: Based on 404,001 firm-level observations. Employment growth is bounded between -200 and 200, based on the method in equation [1]. Employment growth is from March to December 2020. Firm age and size are for 2018-19.

Source: Authors calculation based on STP and BIT data. 
Figure A.1. Payroll Jobs by Division
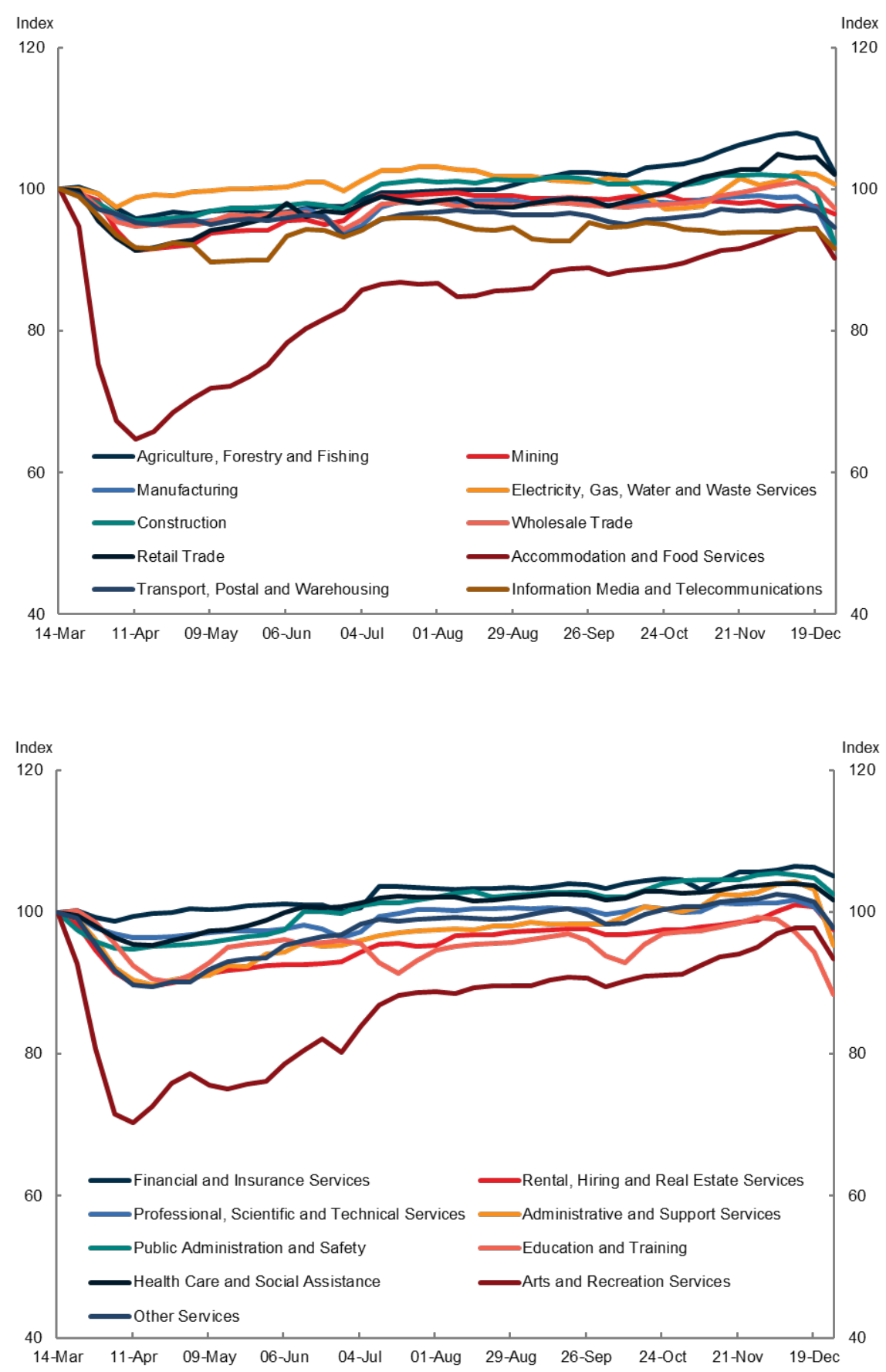

Note: Payroll jobs index, ABS Weekly Payroll Jobs and Wages, Australia. Series indexed to week ending 14 March 2020. Source: ABS Weekly Payroll Jobs and Wages in Australia. 
Figure A.2. Widespread heterogeneity in firm performance

A: Distribution of employment growth in STP

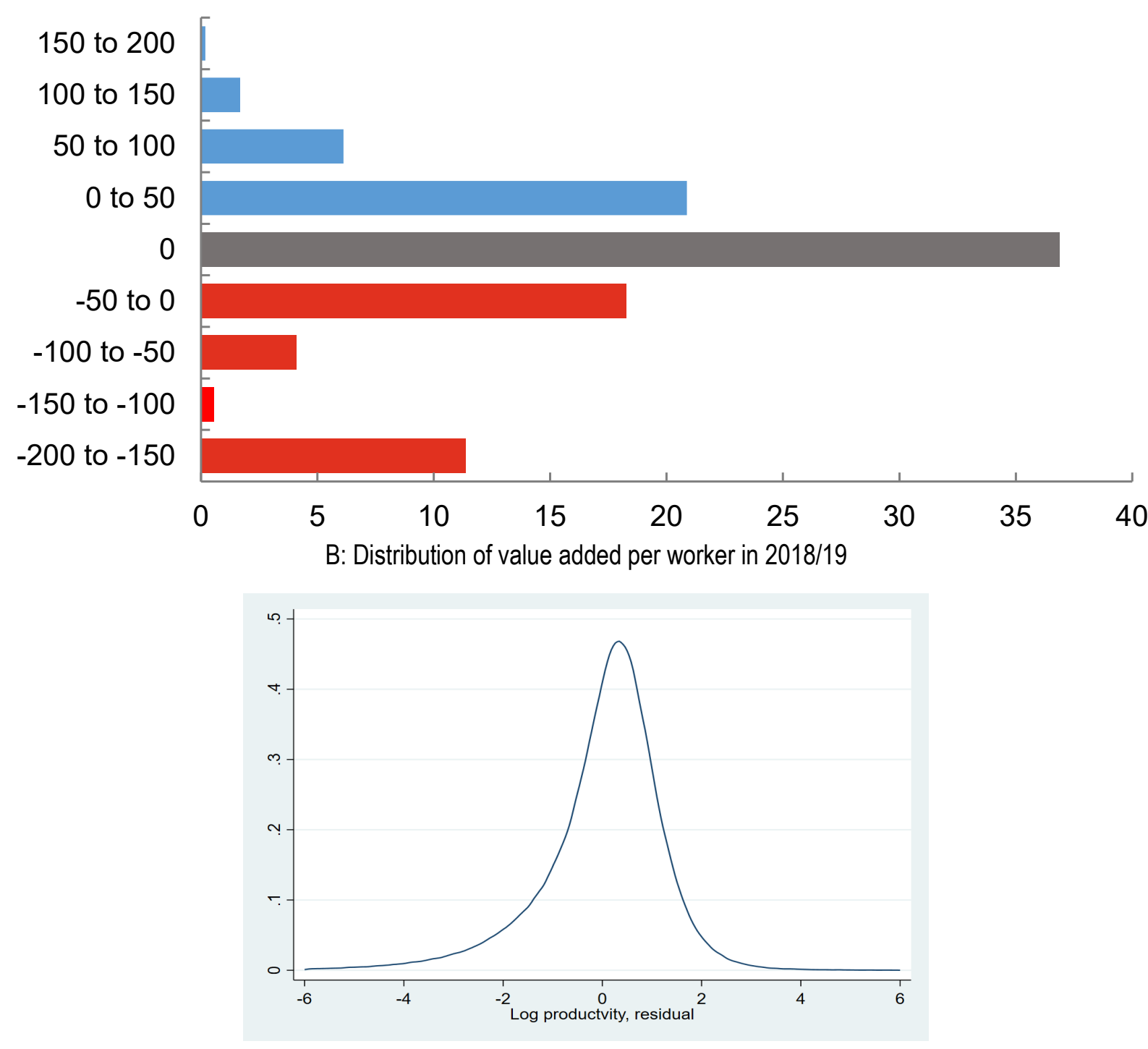

Note: Panel A shows the distribution of employment growth from March to December 2020. Panel B plots the average of the (4 digit) withinindustry distributions, based on the residuals of a regression of log value added per worker on 4-digit industry dummies.

Source: Authors calculation based on STP. 
Table A.3. Firm-level growth and exit responsiveness to productivity: role of firm size Dependent variable: change in firm-level employment or probability of exit from March 2020 to December 2020.

\begin{tabular}{|c|c|c|}
\hline & $\begin{array}{c}\text { Change in Employment growth } \\
\text { (1) }\end{array}$ & $\begin{array}{l}\text { Probability of Firm Exit } \\
\text { (2) }\end{array}$ \\
\hline \multicolumn{3}{|l|}{ Productivity } \\
\hline$<=4$ employees & $\begin{array}{c}2.640^{\star \star \star} \\
(0.246)\end{array}$ & $\begin{array}{l}-0.0155^{\star \star \star} \\
(0.00138)\end{array}$ \\
\hline 5-19 employees & $\begin{array}{c}3.007^{\star * *} \\
(0.171)\end{array}$ & $\begin{array}{l}-0.0187^{\star \star *} \\
(0.000971)\end{array}$ \\
\hline 20-49 employees & $\begin{array}{c}1.868^{\star * *} \\
(0.459)\end{array}$ & $\begin{array}{l}-0.00857^{\star *} \\
(0.00292)\end{array}$ \\
\hline 50-199 employees & $\begin{array}{c}1.488^{\star * *} \\
(0.444)\end{array}$ & $\begin{array}{l}-0.00435 \\
(0.00281)\end{array}$ \\
\hline$>=200$ employees & $\begin{array}{c}1.249 \\
(0.920)\end{array}$ & $\begin{array}{l}0.0014 \\
(0.0028)\end{array}$ \\
\hline Constant & $\begin{array}{l}-45.93^{\star \star \star} \\
(1.604)\end{array}$ & $\begin{array}{l}0.311^{\star \star \star} \\
(0.0103)\end{array}$ \\
\hline \multicolumn{3}{|l|}{ Controls and Fixed Effects } \\
\hline Industry x State & Yes & Yes \\
\hline Firm Size Class & Yes & Yes \\
\hline Firm Age Class & Yes & Yes \\
\hline Number of observations & 403,693 & 492,477 \\
\hline Adjusted R-squared & 0.0272 & 0.0634 \\
\hline
\end{tabular}

Note: Standard errors clustered at the state*industry level.

Source: Authors calculation based on STP and BIT data.

Table A.4. Firm-level growth and exit responsiveness to productivity: role of firm age

Dependent variable: change in firm-level employment probability of exit from March 2020 to December 2020.

\begin{tabular}{|c|c|c|}
\hline & $\begin{array}{c}\text { Change in Employment growth } \\
\text { (1) }\end{array}$ & $\begin{array}{l}\text { Probability of Firm Exit } \\
\text { (2) }\end{array}$ \\
\hline \multicolumn{3}{|l|}{ Productivity } \\
\hline$<=2$ years & $\begin{array}{l}2.467^{\text {*** }} \\
-0.346\end{array}$ & $\begin{array}{l}-0.0128^{\star \star *} \\
-0.00142\end{array}$ \\
\hline $3-5$ years & $\begin{array}{l}2.737^{\star \star \star *} \\
-0.237\end{array}$ & $\begin{array}{l}-0.0151^{\star \star \star} \\
-0.0012\end{array}$ \\
\hline $6-10$ years & 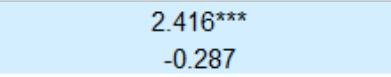 & $\begin{array}{l}-0.0124^{\star \star \star} \\
-0.00124\end{array}$ \\
\hline $11-20$ years & 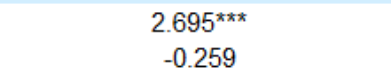 & $\begin{array}{l}-0.0163^{\text {*** }} \\
-0.0015\end{array}$ \\
\hline$>20$ years & $\begin{array}{l}2.450^{\star \star \star *} \\
-0.244\end{array}$ & $\begin{array}{l}-0.0166^{* * *} \\
-0.00164\end{array}$ \\
\hline Constant & $\begin{array}{l}-45.36^{* \star *} \\
-1.633\end{array}$ & $\begin{array}{l}0.307^{\star \star \star} \\
-0.0104\end{array}$ \\
\hline \multicolumn{3}{|c|}{ Controls and Fixed Effects } \\
\hline Industry x State & Yes & Yes \\
\hline Firm Size Class & Yes & Yes \\
\hline Firm Age Class & Yes & Yes \\
\hline Number of observations & 403,693 & 492,477 \\
\hline Adjusted R-squared & 0.0272 & 0.0633 \\
\hline
\end{tabular}

Note: Standard errors clustered at the state ${ }^{*}$ industry level.

Source: Authors calculation based on STP and BIT data. 
Figure A.3. Difference in performance between high and low productivity firms: by industry Change in employment from March 2020 to specified month

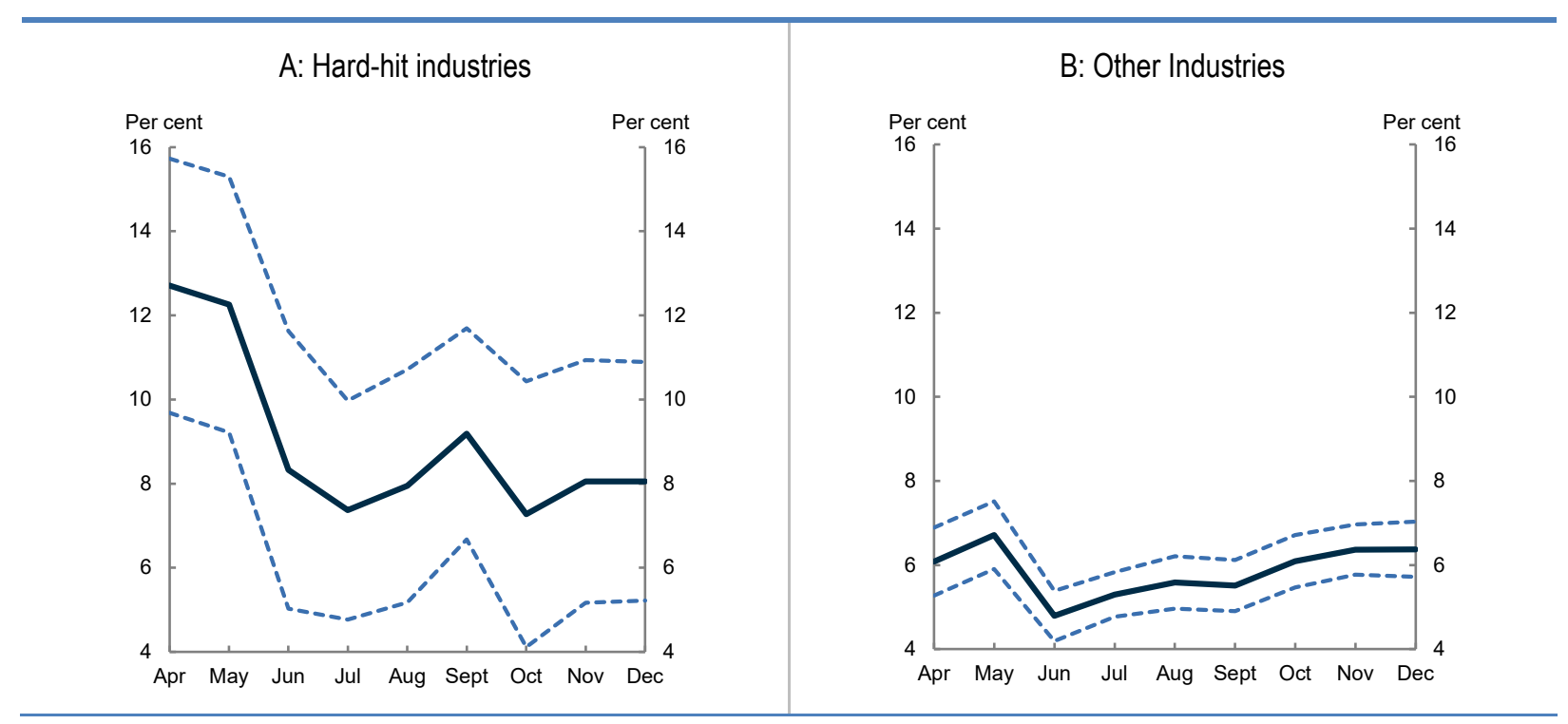

Note: The solid line shows the estimated difference in employment growth between a high productivity firm (one with LP 1 standard deviation above the industry mean) and a low productivity firm (one with LP 1 standard deviation below the industry mean). The dashed line denotes the 90 percent confidence intervals. Based on specification in Table 1 column (1) run for different periods. Hard-hit industries are Accommodation and Food Services, and Arts and Recreation Services. 


\section{Annex B. Robustness tests}

Table B.1. Firm-level growth and exit responsiveness to productivity: turnover-based productivity Dependent variable: change in firm-level employment and probability of exit from March 2020 to December 2020.

\section{Employment growth Probability of firm exit}

(1)

(2)

\begin{tabular}{lcc}
\hline Productivity & $2.635^{* * *}$ & \\
Labour productivity $y_{\text {isr }}$ & $(0.164)$ & $-0.0158^{* * *}$ \\
& $-49.94^{* * *}$ & $0.000958)$ \\
Constant & $(1.903)$ & $(0.0111)$ \\
Controls and fixed effects & & \\
Industry x State & Yes & Yes \\
Firm size class & Yes & Yes \\
\hline Firm age class & Yes & Yes \\
Number of observations & 435026 & 533837 \\
Adjusted R squared & 0.0275 & 0.0630 \\
\hline \hline
\end{tabular}

Note: Standard errors clustered at the state*industry level.

Source: Authors calculation based on STP and BIT data.

Table B.2. Firm-level growth and exit responsiveness to productivity: alternate headcount metrics

Dependent variable: change in firm-level employment and probability of exit from March 2020 to December 2020.

\begin{tabular}{lcc}
\hline \hline & $\begin{array}{c}\text { Employment growth } \\
(1)\end{array}$ & $\begin{array}{c}\text { Probability of firm exit } \\
(2)\end{array}$ \\
\hline Productivity & & \\
Labour productivity ${ }_{\text {isr }}$ & $2.439^{* * *}$ & $-0.0149^{* * *}$ \\
& $(0.129)$ & $(0.000690)$ \\
Constant & $-42.82^{* * *}$ & $0.306^{* * *}$ \\
Controls and fixed effects & $(1.339)$ & $(0.00720)$ \\
Industry $x$ State & & \\
Firm size class & Yes & Yes \\
Firm age class & Yes & Yes \\
Number of observations & Yes & 492477 \\
Adjusted R squared & 401971 & 0.0632 \\
\hline \hline
\end{tabular}

Note: Standard errors clustered at the state*industry level.

Source: Authors calculation based on STP and BIT data. 
Table B.3. JobKeeper Scheme take-up and profitability

Dependent variable: probability that a firm participates in JobKeeper

\begin{tabular}{lcc|cc}
\hline & \multicolumn{2}{c|}{ JobKeeper 1.0} & \multicolumn{2}{c}{ JobKeeper 2.0} \\
& $(1)$ & $(2)$ & $(3)$ & $(4)$ \\
\hline Productivity & & & & \\
ROA $_{\text {isr }}$ & $0.0251^{* * *}$ & & $-0.0173^{* * *}$ & \\
Loss-maker & $(0.0027)$ & & $(0.0024)$ & \\
& & $-0.0151^{* * *}$ & & $0.0083^{* * *}$ \\
\hline Balance sheet & & $(0.0016)$ & & $(0.0014)$ \\
\hline Liquidisr & & & & \\
Fixed share of expenses & & & \\
isr & $0.0629^{* * *}$ & $0.0500^{* * *}$ & $0.0228^{* * *}$ & $0.01289^{* * *}$ \\
Controls and Fixed Effects & $(0.0020)$ & $(0.0020)$ & $(0.0018)$ & $(0.0017)$ \\
\hline Wage share of expenses & $0.204^{* * *}$ & $0.163^{* * *}$ & $0.221^{* * *}$ & $0.185^{* * *}$ \\
\hline Firm Size Class & $(0.0107)$ & $(0.0094)$ & $(0.0095)$ & $(0.0083)$ \\
\hline Firm Age Class & & & & \\
\hline Industry & Yes & Yes & No & Yes \\
\hline State & Yes & Yes & Yes & Yes \\
Number of observations & Yes & Yes & Yes & Yes \\
Adjusted R-squared & Yes & Yes & Yes & Yes \\
\hline \hline
\end{tabular}

Note: Constant not shown. Standard errors clustered at the state*industry level. ROA defined as earning before interest and tax (EBIT), divided by assets. Loss-maker is an indicator that takes on 1 if the firms has negative EBIT.

Source: Authors calculation based on BIT data. 